\title{
Pressão atmosférica e natureza da ciência: uma sequência didática englobando fontes primárias ${ }^{+*}$
}

Deyzianne Santos Fonseca ${ }^{1}$

Mestranda em Ensino de Ciências - UFRN

Juliana Mesquita Hidalgo Ferreira Drummond ${ }^{2}$

Departamento de Física - UFRN

Wesley Costa de Oliveira ${ }^{3}$

Doutorando em Ensino de Ciências - UFRN

Giovanninni Leite de Freitas Batista ${ }^{4}$

Instituto Federal de Educação do Rio Grande do Norte

Daniel Brito de Freitas ${ }^{5}$

Departamento de Física - UFRN

Natal - RN

\section{Resumo}

O presente artigo apresenta uma sequência didática, de perspectiva histórico-filosófica, cujo objetivo é trazer contribuições para o ensino do conceito de pressão atmosférica e a inserção de discussões sobre a natureza do conhecimento científico na educação básica. Busca-se contemplar a compreensão de aspectos da construção histórica do conceito científico em atividades que despertam o pensamento crítico. Propõe-se que os estudantes se engajem em processo "investigativo" sobre determinado fenômeno físico e confrontem suas explicações às que emergem da interpretação diacrônica de excertos de fontes primárias, devidamente contextualizados ao longo das etapas. Sugere-se uma sequência didática mediada,

\footnotetext{
${ }^{+}$Air pressure and nature of science: a didactic sequence with primary sources

* Recebido: março de 2016.

Aceito: novembro de 2016.

${ }^{1}$ E-mail: deyzifonseca@yahoo.com.br

2 E-mail: juliana_hidalgo@yahoo.com

3 E-mail: wesleyoliveira177@yahoo.com

4 E-mail: giovanninni@gmail.com

5 E-mail: danielbrito@dfte.ufrn.br
} 
de caráter dialógico, organizada em momentos de discussão a respeito de conteúdos de ciência e sobre a ciência.

Palavras-chave: Pressão atmosférica; Natureza da Ciência; Fontes primárias.

\begin{abstract}
This paper presentes a didactic sequence based on historical and philosophical approach, which aims to contribute to the teaching of the concept of air pressure and the insertion of discussions on nature of scientific knowledge in basic school. It takes into account the historical construction of this concept in activities that arouse critical thinking. Particularly, students are supposed to engage themselves in an "investigative" process of a given physical phenomenon. They are also supposed to confront their own conceptions to those arising from excerpts of historical sources properly contextualized. It is suggested a mediated intervention of dialogical character, organized in discussions on scientific contents and on nature of science.
\end{abstract}

Keywords: Air pressure; Nature of Science; Primary sources.

\title{
I. Introdução
}

Documentos que compõem a legislação educacional brasileira para o ensino de Física preconizam que "o conhecimento físico seja explicitado como um processo histórico, objeto de contínua transformação" (BRASIL, 2000, p. 24) levando "à compreensão de que modelos explicativos não são únicos nem finais, tendo se sucedido ao longo dos tempos" (BRASIL, 2000, p. 27).

A legislação ecoa aspectos enfatizados por especialistas nas últimas décadas. Vem se frisando a importância da inserção didática de discussões explícitas e contextualizadas sobre a natureza do conhecimento científico (MATTHEWS, 1995; MARTINS, 2006; LEDERMAN, 2007; QUINTAL; GUERRA, 2009; LEDERMAN, 2012; FORATO, 2012; SASSERON; BRICCIA; CARVALHO, 2013; BOAS et al, 2013). Sugere-se a discussão de episódios históricos que contribuam para a contextualização do conhecimento científico como tentativa de resolução de problemas. Dentre outros aspectos, indica-se que:

O estudo adequado de alguns episódios históricos também permite perceber o processo social (coletivo) e gradativo de construção do conhecimento [...] o que contribui para a formação de um espírito crítico e desmistificação do conhecimento científico, sem, no entanto, negar seu valor. [...] O estudo adequado de alguns episódios 
históricos também permite compreender que a ciência não éo resultado da aplicação de um "método cientifico" que permita chegar à verdade (MARTINS, 2006, p. xxixxii).

Considerações sobre o papel da História e Filosofia da Ciência (HFC) no Ensino englobam a utilização de abordagens de cunho histórico-filosófico para a aprendizagem de conceitos científicos (SILVEIRA, 1992; PEDUZZI, 2001; MARTINS, 2006). Sugere-se que a HFC contribui para "uma compreensão melhor dos conceitos científicos por traçar seu desenvolvimento e aperfeiçoamento" (MATTHEWS, 1995, p. 172) e que "a compreensão dos conhecimentos físicos está intrinsicamente relacionada ao entendimento dos problemas a que tais conhecimentos buscaram responder" (MATTHEWS, 1994, p. 50). Pesquisas empíricas evidenciam que propostas metodológicas fundamentadas em aspectos históricos, quando implementadas em sala de aula, podem trazer bons resultados (BOSS; SOUZA FILHO; CALUZI, 2009; BOSS; SOUZA FILHO; CALUZI, 2011; BRICCIA; CARVALHO, 2011; MONTEIRO; MARTINS, 2015).

O entrelaçamento entre a consideração de concepções prévias dos estudantes e abordagens de cunho histórico-filosófico é uma possibilidade pedagógica desenvolvida há décadas em pesquisas na linha HFC no Ensino. Afirma-se com base em pesquisas empíricas que estudantes costumam apresentar ideias enraizadas acerca de fenômenos físicos, as quais podem ser distintas do que a escola pretende ensinar (SALTIEL; VIENNOT, 1985; MELLADO; CARRACEDO, 1993; CARVALHO et al., 1993; NEVES, 1998; PEDUZZI, 2001; MARTINS, 2006). São concepções resistentes a mudanças e não deveriam ser ignoradas:

[...] o conhecimento não é transferido para a mente das pessoas, e sim construído a partir de ideias previamente estabelecidas por elas. [...] Os alunos vêm para as salas de aula com ideias prévias sobre tópicos a serem trabalhados, ideias estas construídas espontaneamente através de sua interação com a natureza ou nas relações sociais. [...] Por elas serem construídas espontaneamente, na maioria das vezes, estão em discordância com o conhecimento cientificamente aceito, logo, também diferenciado daquele ensinado pelos professores nas aulas de Ciências. Porém, isso não quer dizer que elas estejam totalmente incorretas e devam ser deixadas de lado no processo de ensino e aprendizagem, mas sim, que são o ponto de partida deste mesmo processo (LONGHINI; NARDI, 2009, p. 9).

Afirma-se certo papel para a HFC no Ensino, tendo em vista semelhanças (guardados os diferentes contextos ${ }^{6}$ ) entre explicações iniciais dos alunos para fenômenos físicos e visões sustentadas por pesquisadores do passado:

\footnotetext{
${ }^{6}$ Como adverte Peduzzi (2011, p. 19): “É importante observar que o aluno atual vive, pensa e constrói conhecimentos em um mundo diferente daquele vivenciado pelas pessoas e pelos cientistas de outras épocas. Desse modo, esses paralelismos devem ser observados com os devidos cuidados".
} 
As suas resistências são semelhantes às dos próprios cientistas do passado; e mesmo as suas ideias, por mais "absurdas" que pareçam, podem ser semelhantes as que foram aceitas em outros tempos por pessoas que nada tinham de tolas. Embora não haja um paralelo completo entre esses "conceitos prévios" e as concepções cientificas antigas, as semelhanças [...] indicadas são suficientemente fortes para tornar o conhecimento da história da ciência um importante aliado neste trabalho. Examinando exemplos históricos [...] o estudante pode se preparar para aceitar que um processo semelhante ocorra com suas próprias ideias. Pode perceber que, na história, sempre houve discussões e alternativas, que algumas pessoas já tiveram ideias semelhantes às que ele próprio tem, mas que essas ideias foram substituídas por outras mais adequadas e mais coerentes com um conjunto de outros conhecimentos (MARTINS, 2006, p. xxvi).

No contexto educacional, no entanto, a HFC ainda é pouco presente como abordagem didática, mesmo decorridas décadas de pesquisas sobre sua articulação a concepções alternativas. Negligenciam-se, na prática, eventuais repercussões nesse sentido. Costuma-se dar pouca importância a conhecimentos prévios dos alunos e a uma construção contextualizada que valorize o que é trazido para sala de aula (SALTIEL; VIENNOT, 1985; MARTINS, 2006).

Efetivamente, a presença da HFC no contexto escolar ainda é tímida. São insuficientes as iniciativas de utilização de abordagens histórico-filosóficas para ensinar ciência e sobre a ciência (TEIXEIRA; GRECA; FREIRE JR, 2012; PENA; TEIXEIRA, 2013; VITAL; GUERRA, 2014; BEZERRA; 2014). Contribuem para essa situação múltiplos fatores de natureza complexa, como a escassez de materiais didáticos adequados (MARTINS, 2006, p. xxviii; MARTINS, 2007, p. 115) ${ }^{7}$.

Livros didáticos costumam apresentar conhecimentos já elaborados, sem alusão aos problemas que lhe deram origem:

[...] enfatizam os resultados ao qual a ciência chegou - as teorias e conceitos que aceitamos, as técnicas de análise que utilizamos - mas não costumam apresentar algum outro aspecto da ciência. De que modo as teorias e os conceitos se desenvolvem? Como os cientistas trabalham? Quais as ideias que não aceitamos hoje em dia e que eram aceitas no passado? (MARTINS, 2006, p. xxi).

Trazendo "produtos da ciência" dissociados dos seus respectivos processos, os livros costumam colaborar para a propagação de uma visão aproblemática e ahistórica da ciência (GIL PÉREZ et al., 2001). Fomentam uma visão de ciência pronta e acabada, apenas susceptível a pequenos ajustes, o que não repercute a intenção de formar um cidadão apto a buscar soluções para os problemas da sociedade (GUERRA, 2014). Mesmo materiais didáticos que trazem alguns elementos de cunho histórico-filosófico ainda assim costumam ser insuficientes ou incor-

\footnotetext{
7 Aspectos histórico-filosóficos nos livros didáticos não são frequentes e costumam ser esquecidos pelos professores, que em sua maioria dão ênfase à memorização dos conceitos (BATISTA; MOHR; FERRARI, 2007).
} 
rem em visões empiristas-indutivistas da ciência. A produção do conhecimento científico transparece como linear e cumulativa, notadamente fruto de contribuições pontuais de gênios isolados (PAGLIARINI; SILVA, 2006; BATISTA; MOHR; FERRARI, 2007). De acordo com Gil Pérez e outros autores (2001, p. 133):

\section{[...] não se faz um esforço para tornar a ciência acessível [...], nem para mostrar o seu caráter de construção humana, em que não faltam hesitações e erros, situações semelhantes às dos próprios alunos.}

Evidencia-se, portanto, um panorama de lacunas em relação à HFC no contexto educacional e, simultaneamente, potencialidades pedagógicas a explorar.

Nesse contexto, o presente artigo apresenta uma proposta didática de cunho históricofilosófico, a qual pretende contribuir para o ensino do conceito de pressão atmosférica e a discussão da temática natureza da ciência na educação básica. A intervenção de caráter dialógico contempla a interpretação de trechos de documentos históricos em sala de aula. A seção seguinte traz considerações adicionais a respeito das potencialidades didáticas das fontes primárias, as quais são tomadas como aportes.

\section{Ampliando reflexões sobre o uso didático de fontes primárias}

No que diz respeito à utilização didática de fontes primárias da História da Ciência diversas possibilidades e potencialidades vêm sendo identificadas pela literatura atual (BOSS; SOUZA FILHO; CALUZI, 2009; BUENO; PACCA, 2009; BOSS; SOUZA FILHO; CALUZI, 2011; BRICCIA; CARVALHO, 2011; BOSS, 2011; DION; LOURES, 2013; BOSS, 2014; BATISTA, 2014; BATISTA; DRUMMOND; FREITAS, 2015; SILVA; GUERRA, 2015).

Iniciativas direcionadas para o ensino de Física avaliam que:

[...] traduções de fontes primárias em sala de aula, quando aliadas a metodologias específicas para esta abordagem [...] podem trazer importantes elementos para o processo educacional e contribuir para a aprendizagem significativa dos conceitos científicos (BOSS, 2011, p. 24-25).

Também no que concerne a refletir sobre o processo de construção do conhecimento científico, as potencialidades didáticas das fontes primárias vêm sendo elencadas. Encontramse na literatura indicações tais como:

Com o uso destes textos, é possível destacar alguns aspectos essenciais sobre a NdC, tais como a relação do trabalho do cientista com o momento histórico e social que estava sendo vivenciado naquela época; o papel das dúvidas, do levantamento de hipóteses e também do inesperado na construção do conhecimento; o caráter humano da ciência [...] (BRICCIA; CARVALHO, 2011, p. 8). 
[...] o uso desta ferramenta valoriza o ensino e a aprendizagem de aspectos que caracterizamos como componentes básicos da alfabetização científica, tais como uma melhor aprendizagem sobre a natureza da ciência (BRICCIA; CARVALHO, 2011, p. 16).

Apesar das potencialidades elencadas, costuma-se notar que é rara a presença de textos históricos originais em livros didáticos (BATISTA; MOHR; FERRARI, 2007). A utilização desse tipo de material em salas de aula de disciplinas científicas e, em particular, no caso da Física, ainda é escassa ${ }^{8}$.

Há significativa lacuna no tocante a atividades dialógicas, de caráter interpretativo, que concebam as fontes primárias não como meras ilustrações de conteúdo, mas sim como registros de processos vivenciados pelos personagens da História da Ciência, os quais são marcados por suas intencionalidades.

Nesse sentido, uma expressiva inspiração para a utilização didática de fontes primárias da História da Ciência no ensino de Física pode ser observada no uso recorrente de documentos históricos como recursos didáticos na disciplina escolar de História9 ${ }^{9}$.

Nas aulas de História, os documentos históricos não exercem o papel de meros objetos ilustrativos de conteúdos. São considerados como ferramentas pedagógicas capazes de permitir o diálogo entre passado e presente. Em atividades interpretativas de cunho diacrônico, mediadas pelo professor, os alunos são estimulados a abstrações e diferenciações (CAIMI, 2008; XAVIER, 2010).

Indicações metodológicas dessa natureza preconizam o papel ativo do estudante em atividades que despertam o pensamento crítico, desenvolvem a imaginação e a curiosidade. Dessa forma, há uma apropriação didática dos documentos históricos no sentido de desenvolver habilidades de observação, problematização, análise, comparação, formulação de hipóteses, crítica, produção de sínteses, reconhecimento de diferenças e semelhanças, enfim, capacidades que favorecem a construção do conhecimento histórico numa perspectiva autônoma.

São estas habilidades que dão suporte aos alunos para que os mesmos venham a compreender o processo de construção de conhecimento, quer seja este o conhecimento histórico ou científico. Analogamente, portanto, pode-se sugerir para as aulas de Física a utilização didática de fontes primárias da História da Ciência visando à compreensão do processo de construção histórica do conhecimento científico. Destaca-se, por exemplo, a possibilidade de discutir sobre as intencionalidades do pesquisador, o que ocorreu no processo de construção de uma

\footnotetext{
${ }^{8}$ Uma publicação recente, recomendável para consulta de professores, apresenta traduções de textos históricos como subsídios, bem como sequências didáticas para o desenvolvimento de práticas pedagógicas com base em fontes primárias da História da Ciência (SILVA; GUERRA, 2015).

${ }^{9}$ Sobre esse aspecto, uma discussão mais aprofundada pode ser vista em publicação recente da qual participou um dos autores do presente trabalho (BATISTA; DRUMMOND; FREITAS, 2015). Discorre-se sobre a frequente utilização de documentos históricos na disciplina escolar de História, em atividades investigativas de caráter diacrônico. E, por outro lado, são identificadas lacunas quanto ao uso dessas fontes em aulas de Física, particularmente segundo uma perspectiva investigativa (e não meramente ilustrativa), a qual estaria em ressonância com pressupostos historiográficos e objetivos didáticos atualizados.
} 
teoria, como o cientista se comportou no decorrer do desenvolvimento de seu trabalho e quais eram suas pretensões.

No que diz respeito ao reconhecimento de diferenças e semelhanças, a interpretação de fontes primárias permite resgatar explicações do passado e comparações cuidadosas, diacrônicas, entre concepções científicas de épocas distintas podem ser estabelecidas ${ }^{10}$.

Concepções do passado sobre certos fenômenos podem ser comparadas pelos próprios alunos às suas próprias explicações, colaborando para que os mesmos se sintam parte do processo de construção do conhecimento. Esse processo requer o acompanhamento permanente do professor mediador para a contextualização adequada das concepções científicas do passado. Caso contrário, podem emergir compreensões simplistas de que essas ideias seriam pouco razoáveis e triviais.

A perspectiva de utilização didática de fontes primárias em atividades dialógicas de cunho investigativo se articula a questionamentos e posturas cuja inserção no contexto educacional vem sendo preconizada há algum tempo: "Como e por que se aceitou certa ideia? Existiam alternativas? Como e por que essas alternativas foram abandonadas? Quando investigamos o passado, podemos tentar responder a essas questões" (MARTINS, 1989, p. 9).

A atividade investigativa de caráter diacrônico promove o diálogo entre passado e presente, repercutindo objetivos significativos relacionados ao papel da História da Ciência no contexto educacional. Pode-se citar, como exemplo, a compreensão mais profunda de aspectos da metodologia científica no passado e "padrões de mudança na metodologia vigente" (MATTHEWS, 1995, p. 172).

No presente trabalho, a perspectiva balizadora da sequência didática proposta representa uma possibilidade de ir ao encontro dessas considerações. Sugere-se uma sequência de caráter complementar que permite o aprofundamento de aspectos ainda pouco contemplados em livros didáticos. Particularmente, remete-se à possibilidade de abordar conteúdos científicos de forma integrada ao seu processo de construção histórica. As atividades consideram, especialmente, o sentido de colaborar para a compreensão do conceito de pressão atmosférica trazendo à tona recortes históricos do seu processo de construção ${ }^{11}$.

É imprescindível que a utilização da proposta seja permeada por uma contextualização histórica que traga à tona em sala de aula a controvérsia científica em torno da existência do vazio, à qual se integra o desenvolvimento do conceito de pressão atmosférica. Em nota subse-

\footnotetext{
${ }^{10}$ A interpretação diacrônica das fontes primárias em sala de aula se baseia na sintonia entre pressupostos historiográficos atuais e a utilização didática desses recursos (VIDEIRA, 2007; FORATO; PIETROCOLA; MARTINS, 2011; BATISTA; DRUMMOND; FREITAS, 2015).

${ }^{11}$ A temática histórica específica foi escolhida devido ao seu relevante potencial didático ainda pouco explorado. No Brasil, iniciativas de autores do presente trabalho (OLIVEIRA, 2013; BATISTA; DRUMMOND; FREITAS, 2015) buscam explorar essas potencialidades e vem se somando a outros poucos trabalhos que utilizam essa temática histórica para fins didáticos (COELHO; NUNES, 1992; PORTELA, 2006; LONGHINI; NARDI, 2009).
} 
quente, são indicados materiais didáticos elaborados para a Educação Básica na forma de narrativas histórico-pedagógicas e jornais históricos. Esses recursos didáticos podem ser úteis para a contextualização das fontes primárias destacadas na sequência didática.

Por seu turno, para a condução da intervenção, é fundamental que o professor mediador perceba as motivações dos pensadores do passado, esteja familiarizado com aspectos relacionados às bases epistemológicas e filosóficas do "horror ao vazio", de modo a compreender a complexidade dessa concepção e sua relevância ao longo da História da Ciência. Lacunas nessa fundamentação podem levar o próprio docente à concepção equivocada de que teorias do passado, como o "horror ao vazio", são menos criteriosas, espontâneas e se equivalem aos pensamentos dos alunos 12 .

\section{III. (Breve) Contextualização histórica}

A presente seção traz uma breve contextualização histórica que permite vislumbrar alguns aspectos importantes. Esse sucinto panorama é baseado nas seguintes fontes primárias e secundárias, que eventualmente podem ser relevantes como fonte de consulta e aprofundamento: MAGIE, 1969; GRANT, 1981; MARTINS, 1989; SOLAZ-PORTOLÈS; MORENOCABO, 1997; LONGHINI; NARDI, 2002.

Historicamente, o surgimento do conceito de pressão atmosférica se insere nos debates sobre a possibilidade e a existência do vazio. Esses questionamentos se entrelaçaram, ao longo da História da Ciência, a discussões de várias temáticas físicas importantes, como o movimento e a natureza da luz.

$\mathrm{Na}$ Antiguidade, os filósofos "eleatas" negavam que o vazio existisse. Para eles, o vazio seria necessário caso os movimentos existissem. No entanto, consideravam que os próprios movimentos não existiam. Mudanças e transitoriedades eram meras ilusões sensoriais. Os chamados "atomistas" também consideraram o vazio como condição fundamental para o movimento, mas, ao contrário dos eleatas, confiavam nas evidências sensoriais. Aceitavam a existência dos movimentos e, consequentemente, do vazio. Consideravam que os fenômenos físicos podiam ser explicados pelo movimento de partículas indivisíveis, os átomos, em meio a espaços vazios.

A relação entre vazio e movimento foi rejeitada pelo filósofo Aristóteles, no século IV a.C. Para ele, o movimento não evidenciava a existência do vazio. De acordo com o chamado "argumento da troca mútua", sugeriu que ao se moverem os corpos cediam lugar um ao outro.

Aristóteles discutiu sistematicamente outros argumentos dos atomistas e propôs que os fenômenos citados por eles podiam ser explicados sem a hipótese do vazio. Em torno dessas discussões, havia o desenvolvimento de importantes ideias na História da Física. Para os atomistas, os corpos se contraíam nos seus espaços vazios interiores. Já para Aristóteles, os corpos

\footnotetext{
12 Recomenda-se a professores da Educação Básica a consulta a material de apoio sobre a temática histórica, redigido especialmente para esses profissionais por um dos autores do presente trabalho (OLIVEIRA, 2013).
} 
se contraíam expulsando para fora o que continham dentro. Os atomistas consideravam que a luz tinha natureza material. Podia atravessar um aquário cheio sem que ele trasbordasse, justamente devido aos espaços vazios existentes no líquido. Aristóteles, no entanto, argumentou que a luz não era material. Argumentação e contra-argumentação análogas foram aplicadas à propagação do som.

As considerações de Aristóteles foram bastante influentes, mas no período posterior ao filósofo, alguns pensadores se mantiveram favoráveis ao vazio. No século I d. C., Lucrécio relembrou os argumentos atomistas. Na mesma época, Heron de Alexandria combinou o atomismo com algumas concepções aristotélicas, adotando a hipótese do vazio descontínuo. Argumentou que não havia um vazio contínuo na natureza, mas sim pequenas porções de vazio na matéria. Ao explicar o funcionamento de um sifão, Heron considerou que havia certa resistência na natureza à formação de vazios contínuos: "Se retiramos o ar do sifão através da extremidade externa, a água irá imediatamente seguir por causa da impossibilidade de um vácuo contínuo no sifão [...]" (HERON de Alexandria, Pneumatica apud MARTINS, 1989, p. 17).

O estudo das ideias de Aristóteles continuou impulsionando as discussões. A negação do vazio se relacionava a uma visão de mundo aristotélica complexa e intrinsecamente coerente. O universo seria pleno, totalmente preenchido por matéria. A definição de espaço como envoltório ou recipiente de um corpo, excluía a possibilidade de conceber um "espaço vazio". A concepção de que a natureza rejeitava o vazio embasava explicações aristotélicas para vários fenômenos tais como o movimento de projéteis. De acordo com a antiperistasis, o ar atuava como uma causa externa para a manutenção do movimento do objeto lançado. Ocupava o espaço que não podia ficar vazio pelo deslocamento do objeto, empurrando-o para frente.

Criticando algumas ideias aristotélicas, Philophonos defendeu que uma força poderia ser transmitida ao próprio objeto lançado. Essa força se extinguiria progressivamente no vazio. Questionamentos à parte, a impossibilidade de existência do vazio foi de longe a concepção mais aceita no medievo. No século IX, o pensador árabe Avicena retomou a explicação para o funcionamento do sifão. No século XIV, o francês Jean Buridan chegou a se opor a concepções aristotélicas sobre o movimento, defendendo a hipótese do ímpeto. Por outro lado, reforçou o "horror ao vazio" com argumentos empíricos. Explicou, por exemplo, a subida do vinho por um canudo: quando o ar do canudo era puxado, o vinho subia em seguida para evitar a formação de vazio. No mesmo século, seu compatriota Nicholas de Autrecourt argumentou que, quando um corpo se movia, o ar a sua frente se condensava nos espaços vazios internos ao ar. Ele, no entanto, negava a possibilidade de formação de um vazio extenso na natureza.

Experimentos imaginários foram usados nas discussões medievais. Segundo Jean Buridan, um fole perfeitamente fechado, não poderia ter suas paredes separadas nem que vinte cavalos fossem amarrados para puxá-las. O pensador Francisco de Toledo, por sua vez, acrescentou que o fole se quebraria antes da separação dos seus lados. Bernardino Telesio defendeu que, caso o objeto fosse resistente, ele poderia ser aberto, formando um espaço vazio interno. 
O estudioso Marsilius de Inghen sugeriu outro experimento imaginário importante. Colocando um recipiente internamente côncavo, preenchido por ar e totalmente fechado, em certo volume de água intensamente fria, a condensação do ar supostamente deveria levar à formação de um espaço vazio. Como a natureza não permitiria o vazio, a condensação do ar não ocorreria, segundo Marsilius. Pensadores contrários ao "horror ao vazio" sugeriram novas versões para o experimento. O recipiente côncavo, fechado, estaria totalmente cheio de água. Imaginaram que a água, ao se congelar, iria se contrair (atualmente consideraríamos o contrário), deixando um espaço vazio. Nem todos concordaram que isso ocorreria. Francisco de Toledo argumentou que o espaço interno ficaria cheio de "vapores sutis". Outros disseram que o recipiente se quebraria ou a água nem se congelaria.

À exceção de alguns defensores do vazio, como Giordano Bruno (em contexto de valorização das antigas ideias atomistas), até o século XVII, a atitude de negação ao vazio foi emblemática. Francis Bacon retomou argumentos empíricos a respeito do funcionamento de seringas e ventosas em defesa do "horror ao vazio". René Descartes, por sua vez, foi um dos grandes representantes da oposição ao vazio. Descartes considerava a razão suficiente para negar a possibilidade de existência de espaço sem substância. Para ele, a extensão era a propriedade que caracterizava os corpos.

Ao longo da Revolução Científica, os debates sobre o vazio prosseguiam. Outras contribuições a essas discussões emergiram da recorrência de questionamentos sobre a possibilidade de o ar ter peso e exercer pressão. Partindo de textos de Arquimedes, Simon Stevin afirmou que os corpos imersos na água eram pressionados por todos os lados. Isaac Beeckman, aluno de Stevin, considerou por analogia que no ar pudesse ocorrer o mesmo. A matéria seria empurrada pelo ar em direção aos espaços vazios. Isso ocorreria, por exemplo, em bombas d'água, segundo Beeckman. Comuns na época, esses mecanismos eram até então explicados com base no "horror ao vazio".

A proposta de Beeckman sobre o ar não foi aceita prontamente. Além disso, considerar que o ar tinha peso e exercia pressão, não necessariamente implicava negar o "horror ao vazio". A postura de René Descartes pode ser tomada como exemplo. Ele considerou as indicações sobre o ar e, ao mesmo tempo, foi um dos mais fortes oponentes ao vazio.

No mesmo período, ocorreram outros episódios. O pesquisador Giovanni Baliani escreveu uma carta para Galileu Galilei comentando sobre o problema de um sifão que não conseguia elevar água até uma colina de $21 \mathrm{~m}$. Galileu Galilei considerava a aversão da natureza à formação de vazios extensos. Respondeu que a água se elevava no sifão devido à "força do vácuo". As porções de matéria tendiam a ficar juntas de forma a evitar o vazio. No entanto, havia um ponto crítico - pouco mais de $10 \mathrm{~m}$ - no qual a coluna de água se rompia, sendo impossível "esticar" a água até $21 \mathrm{~m}$ de altura. Baliani não concordou com a explicação. Pensava de forma semelhante a Beeckman. $\mathrm{O}$ ar atuava na superfície do reservatório, pressionando a água, forçando-a a subir pelo tubo. No entanto, como a própria água também tinha peso, a 
pressão do ar conseguia fazer com que ela fosse elevada somente até certa altura limite de cerca de $10 \mathrm{~m}$.

Ainda no século XVII, um experimento interessante foi realizado por Gasparo Berti. Ele preparou um tubo de chumbo bem longo, equivalente a um edifício de dois andares, com uma torneira na parte inferior. O tubo foi preenchido com água e colocado em um tonel também com água. Quando a torneira foi aberta, a água desceu pelo tubo, permanecendo nele uma coluna com a altura máxima já prevista. Os pesquisadores passaram a discutir sobre o que havia ficado acima da coluna de água. Seria relevante visualizar o interior do tubo, mas não havia como preparar um tubo de vidro com aquelas dimensões. Variações do experimento foram realizadas e os pesquisadores continuaram divergindo: o espaço superior estava ou não vazio?

Evangelista Torricelli, discípulo de Galileu Galilei, soube a respeito desse experimento e pode ter sido proveniente do próprio Galileu (ou de seu discípulo Vincenzo Vivianni) a ideia de utilizar mercúrio no lugar da água. Galileu considerava que a altura máxima atingida por um líquido seria inversa ao seu peso específico. A coluna máxima de mercúrio seria bem menor e, nesse caso, seria possível utilizar um tubo de vidro.

Foi justamente, portanto, no contexto de discussões sobre a existência do vazio que Evangelista Torricelli deu início aos seus trabalhos (e Blaise Pascal, posteriormente, o seguiu nessa empreitada). Torricelli repetiu o experimento de Berti com um tubo de vidro portátil. Investigou se a parte superior do tubo estava vazia. E, mesmo admitindo que defendia uma explicação dissidente, afirmou que o mercúrio era empurrado ao longo do tubo pelo ar que pressionava a superfície do líquido no recipiente. Para ele, a explicação para a sustentação da coluna de mercúrio baseada na atuação da pressão atmosférica era suficiente.

O interesse em torno da controvérsia sobre o vazio permaneceu. Blaise Pascal, em seus tratados, dedicou-se ao assunto. Adicionalmente, com a ajuda de colaboradores, colocou em prática a sugestão de realizar o experimento de Torricelli ao longo da subida de uma montanha. A sugestão, aparentemente de Descartes, tomava como ponto de partida o decréscimo da pressão atmosférica com a altitude. De fato, notou-se que a altura da coluna de mercúrio diminuiu ao longo da subida da montanha Puy-de-Dôme, na terra natal de Pascal. A pressão atmosférica seria, assim, responsável pela sustentação da coluna de mercúrio. Essa interpretação, no entanto, foi passível de contestação na época: talvez o "horror ao vazio" variasse com a altitude. As investigações continuaram. $\mathrm{O}$ experimento de Torricelli foi realizado em uma caixa evacuada e a coluna de mercúrio desceu.

Com o passar do tempo, novos estudos e argumentos, o "horror ao vazio" foi perdendo adeptos. Prevaleceram as explicações que encontramos em nossos livros didáticos de física. $\mathrm{O}$ experimento mais conhecido de Torricelli é citado de forma descontextualizada. A atuação da pressão atmosférica parece ter sido a explicação permanente e exclusiva. Todo o significativo processo histórico no qual o experimento se inseriu é ignorado. Há pouca ou nenhuma alusão ao debate a respeito do vazio. Essas lacunas são pontos de partida para a sequência didática apresentada a seguir. 


\section{A sequência didática em linhas gerais}

De acordo com referenciais que tratam da construção de sequências didáticas, considera-se a elaboração desse tipo de proposta um processo complexo que contempla diversas escolhas. Deve-se levar em conta tanto o conhecimento a ser ensinado quanto as visões iniciais de quem aprende (BUTY; TIBERGHIEN; MARÉCHAL, 2004; MÉHEUT; PSILLOS, 2004).

Particularmente, o processo de transposição didática da História da Ciência requer a consulta a recursos de natureza complexa, os quais englobam documentos históricos e trabalhos especializados produzidos por historiadores da ciência. Segundo Dion e Loures (2013, p. 201): "É somente a partir daí que se pode adquirir um critério de escolha, de forma a fazer um recorte [...] que atenda aos objetivos [pedagógicos] previamente definidos".

No caso da proposta apresentada a seguir seria inviável contemplar, em perspectiva internalista e externalista, numa única intervenção, todas as concepções científicas presentes ao longo da História da Ciência a respeito dos fenômenos físicos em questão. Evidentemente, outras escolhas poderiam ter sido realizadas ${ }^{13}$.

Quanto à seleção dos textos históricos foi determinante: a adequação da formulação discursiva ao nível escolar visado, a expressão de ideias científicas em relação às quais se nota certo paralelismo com concepções alternativas citadas na literatura da pesquisa em ensino de Física $^{14}$; uma percepção mais ampla do significado dos episódios históricos abordados no tocante à construção do conhecimento físico em questão. Foram também levadas em conta certas considerações: "é necessário selecionar um trecho inteligível ao aluno, despertar nele algum interesse, e não ser demasiado longo do ponto de vista do nível de escolaridade focado" (FORATO; MARTINS; PIETROCOLA, 2012, p. 135).

A sequência didática sugerida aborda os recortes específicos do ponto de vista conceitual, discute significados físicos, bem como contextualiza reflexões sobre a natureza do conhecimento científico. Tem caráter essencialmente dialógico e visa contribuir para a inclusão da HFC no ensino de Física, de forma que os estudantes reconheçam as fontes primárias enquanto artefatos culturalmente constituídos e sujeitos a interpretações. Busca despertar a imaginação, a curiosidade e o pensamento crítico dos alunos.

A proposta sintetizada no Quadro 1 privilegia a concepção de que o conhecimento físico se relaciona à investigação de problemas. Sugere-se que os estudantes se engajem em tentativa inicial de construção de explicações para o seguinte fenômeno do cotidiano: a subida de líquido por um canudo. Em seguida, adota-se a perspectiva de que os alunos sejam convidados a interpretar trechos específicos de fontes primárias com o auxílio de mediação realizada

\footnotetext{
${ }^{13}$ Em relação aos recortes realizados, é importante frisar que, ao longo da sequência didática, o contexto científico é destacado e sua influência explorada, ao passo que aspectos econômicos, sociais e políticos dos períodos citados não. A proposta não apoia a visão de pesquisador neutro, alheio a esses aspectos. Por outro lado, contemplá-los não foi prioridade na elaboração da mesma.

14 Como afirma Solaz-Portolès (2008, p. 3): “em muitos casos nossos alunos sustentam, concepções plenistas ou negadoras do vazio e [...] estas coincidem em grande medida com ideias que aparecem em certos momentos da história da ciência".
} 
pelo professor de Física. Busca-se promover o engajamento dos estudantes em atividade investigativa que resgata elementos da construção histórica do conhecimento físico em questão.

Com apoio da mediação, sugere-se que os próprios alunos confrontem suas explicações iniciais para a subida do líquido às que emergem da interpretação de trecho de uma fonte primária específica. No recorte selecionado, o pensador medieval Jean Buridan explica o mesmo fenômeno com base no "horror ao vazio". Na continuidade da sequência didática, é imprescindível uma contextualização histórica que traga à tona os debates a respeito da existência do vazio, destacando a relevância e complexidade das discussões da ciência do passado, de forma a evitar visões simplistas. Propõe-se que os alunos sejam convidados à interpretação de outros trechos específicos de fontes primárias. Esses trechos fazem referência ao peso do ar, à atuação da pressão atmosférica e citam a possibilidade de explicar determinados fenômenos de forma alternativa ao "horror ao vazio". No decorrer da proposta, os estudantes são convidados a examinar de forma crítica escritos de Torricelli, os quais contribuem para uma compreensão contextualizada do famoso experimento. Finalizando a sequência, sugere-se que os estudantes considerem a possibilidade de reexaminar o fenômeno físico discutido inicialmente.

Considerando iniciativas semelhantes desenvolvidas em relação a outros conceitos (BUENO; PACCA, 2009), propõe-se, portanto, uma sequência didática na qual os alunos se engajem em processo "investigativo" que lhes permita: a percepção de semelhanças (e diferenças) entre suas próprias explicações iniciais e concepções expressadas por pensadores do passado em documentos históricos; a compreensão de elementos relacionados ao processo histórico de construção do conceito de pressão atmosférica; a percepção da inexistência ou da fragilidade desse fator em suas explicações iniciais e a possibilidade de reconsiderá-las à luz desse elemento.

Considera-se que uma possível contribuição para o entendimento do conceito físico de pressão atmosférica possa se delinear na medida em que o referido conceito seja considerado pelos estudantes como base para reinterpretação do fenômeno físico inicialmente submetido a problematização.

Quadro 01 - A sequência didática em momentos específicos.

\begin{tabular}{|l|l|}
\hline $\begin{array}{l}\text { Momento 1 } \\
\text { Parte 1 }\end{array}$ & Tentativa inicial de explicar a subida de líquido por um canudo. \\
\hline $\begin{array}{l}\text { Momento 1 } \\
\text { Parte 2 }\end{array}$ & $\begin{array}{l}\text { Atividade dialógica de interpretação de fonte primária medieval (Jean Buri- } \\
\text { dan explica a subida do líquido com base no "horror ao vazio"). } \\
\text { Contextualização histórica sobre as discussões a respeito do vazio. }\end{array}$ \\
\hline Momento 2 & $\begin{array}{l}\text { Utilização de experimento histórico e trechos de fontes primárias relaciona- } \\
\text { das ao "peso do ar". } \\
\text { Atividade dialógica de interpretação de fonte primária da Revolução Cientí- } \\
\text { fica (Isaac Beeckman expressa: o ar é "pesado" e "nos pressiona de todos os } \\
\text { lados"). }\end{array}$ \\
\hline
\end{tabular}




\begin{tabular}{|c|c|}
\hline & $\begin{array}{l}\text { Extrapolação: Beeckman concordaria com a explicação de Buridan para o } \\
\text { fenômeno do canudo? } \\
\text { Continuidade da contextualização histórica. }\end{array}$ \\
\hline Momento 3 & $\begin{array}{l}\text { Utilização de livro (s) didático (s) de Física, com destaque para o Experi- } \\
\text { mento de Torricelli. Problematização a partir de lacunas observadas. }\end{array}$ \\
\hline Momento 4 & $\begin{array}{l}\text { Atividade dialógica utilizando entrevista fictícia elaborada com recortes de } \\
\text { escritos de Evangelista Torricelli. } \\
\text { Reflexão sobre aspectos não respondidos em momentos anteriores. } \\
\text { Retorno à questão inicial: o fenômeno da subida do líquido pode ser (re) in- } \\
\text { terpretado com base na concepção de pressão atmosférica? } \\
\text { Síntese de reflexões sobre a Natureza da Ciência. }\end{array}$ \\
\hline
\end{tabular}

A seção seguinte do presente artigo detalha os momentos que compõem a proposta. Os referenciais da linha de pesquisa HFC no Ensino são, nesse caso, direcionados para tema histórico e conteúdo científico em destaque. Explicitando seus elementos norteadores, são citadas pesquisas sobre concepções alternativas a respeito dos fenômenos em questão e eventuais articulações com a História da Ciência. Da mesma forma, faz-se referência a algumas lacunas e distorções históricas observadas em livros didáticos a respeito dos conteúdos focalizados ${ }^{15}$.

\section{Detalhamento da sequência didática}

\section{Momento I - Primeira parte}

Por que recipientes dotados de tampa do tipo "abre fácil", como latas de extrato de tomate, potes de requeijão ou vidros de palmito só se abrem após a retirada do anel de plástico? O que significa aquele ruído notado quando abrimos um pacote de café embalado a vácuo?

Esses são exemplos de fenômenos que costumam chamar a atenção das pessoas, as quais podem tentar explicá-los com base em suas vivências, escolares ou não. Referenciais atuais para a inserção da HFC no Ensino sugerem que os estudantes devem ser colocados situações contextualizadas que façam sentido, possibilitando uma relação crítica com a sua própria realidade (GUERRA, 2014). Poderia ser um ponto de partida interessante, em sala de aula, tentar explicar situações, como o funcionamento de sifões e o uso de canudos para sorver líquidos.

\footnotetext{
$15 \mathrm{O}$ objetivo do presente trabalho é apresentar de maneira fundamentada a referida sequência didática. Convém destacar que a mesma foi aplicada em minicurso para alunos do Ensino Médio em escola pública do município de Natal (RN). Na ocasião, realizou-se pesquisa empírica que buscou investigar a contribuição da proposta no tocante aos objetivos supracitados. Os estudantes demonstraram bastante interesse ao longo da intervenção. Em suas reflexões iniciais, em geral, não citaram a ideia de "pressão atmosférica", embora formalmente já tivessem contato com o conteúdo em sala de aula. Por outro lado, essa concepção esteve presente de modo acentuado nas reflexões individuais escritas realizadas após o minicurso. Os resultados da aplicação de instrumentos de pesquisa foram apresentados no XVI EPEF (FONSECA; DRUMMOND; OLIVEIRA, 2016; OLIVEIRA; FONSECA; DRUMMOND, 2016). Registros audiovisuais realizados estão em processo de análise e serão contemplados em futuras publicações.
} 
Do ponto de vista científico atual, tais fenômenos estão relacionados à pressão atmosférica. No entanto, as referências de estudantes de diferentes níveis educacionais a esse conceito costumam ser pouco adequadas. Pesquisas empíricas sobre concepções alternativas registram que muitos estudantes consideram, no caso de fenômenos como a subida do líquido pelo canudo “[...] o ato de sugar como o responsável pela criação de uma pressão. A ideia de sucção está constantemente presente em resultados de pesquisas envolvendo situações experimentais como essa" (LONGHINI; NARDI, 2009, p. 16).

Concebem que há uma atividade interna ao canudo, e nada de relevante para a situação acontece fora dele. O sugar é algo interno e suficiente para a subida do líquido. Trata-se de uma atividade sensório motor, mecânica, que relaciona de forma imediata o ato de sugar à subida do líquido. O líquido é sugado. $\mathrm{O}$ ar é sugado e o líquido sobe em seguida para ocupar esse lugar vazio deixado pelo ar. Quando questionados sobre esse tipo de fenômeno, muitos alunos sustentam explicações "plenistas" que guardam semelhanças com a concepção conhecida como "horror ao vácuo" (SOLAZ-PORTOLÈS, 2008; LONGHINI; NARDI, 2009) ${ }^{16}$.

No ambiente educacional, os livros didáticos ao se referirem à temática "pressão atmosférica" costumam negligenciar as possíveis explicações que os alunos sugeririam para fenômenos cotidianos, como aqueles citados no início dessa seção. As explicações científicas atuais vão de encontro àquelas que em princípio seriam sugeridas pelos alunos. Apesar disso, espera-se deles aquiescência imediata à "verdade científica" (SILVEIRA, 1992; MARTINS, $2006)^{17}$.

O conceito de pressão atmosférica é apresentado como "verdade pronta" pelos livros didáticos, desconsiderando as visões iniciais dos estudantes e, ao mesmo tempo, sem alusão ao contexto em que tal conceito foi concebido historicamente. $\mathrm{O}$ entrelaçamento entre concepções prévias e História da Ciência é uma possibilidade pedagógica (VILLATORRE; HILGA; TYCHANOWICZ, 2008) que costuma ser ignorada em materiais didáticos. Negligenciam-se repercussões didáticas representadas por eventuais semelhanças entre as ideias prévias dos estudantes e as concepções históricas fundamentadas no "horror ao vácuo".

À luz das referidas ponderações, sugere-se a primeira etapa da sequência didática. Os alunos são convidados a refletir sobre uma ação do cotidiano: tomar suco ou refrigerante utilizando um canudo plástico. A intenção inicial é questioná-los sobre o fenômeno da subida do líquido pelo canudo.

\footnotetext{
16 Outros fenômenos relacionados, como o funcionamento de seringas e bebedouros de pássaros, costumam ser citados em trabalhos sobre concepções alternativas no ensino de Física (SOLAZ-PORTOLÈS, 2008; REKOVVSKY, 2012).

17 Como exemplo, podemos citar referência ao fenômeno de tomar refresco com canudinho em um livro didático de Física relativamente recente (MÁXIMO; ALVARENGA, 2006, p. 240). Apenas a explicação atual é apresentada. Não há alusão a outras explicações ao longo da História da Ciência. Transmite-se a impressão de que a explicação atual é e sempre foi a verdade, óbvia, incontestável.
} 
Os questionamentos citados a seguir decorrem de consideração desse tipo de resultado expresso em pesquisas empíricas sobre concepções sustentadas por estudantes. São sugestões para reflexão na primeira etapa da sequência didática.

- Por que o líquido sobe através do canudo?

- O que você suga pelo canudo?

- O líquido sobe por que tiramos o ar de dentro do canudo? Como assim? Fica um espaço dentro dele vazio? O que, então, ocorre com o líquido?

- Se o canudo estiver furado, vai ocorrer a subida do líquido? Por quê?

- O ar entra pelo furo no canudo e ocupa o espaço que ficaria vazio? Isso explica, nesse caso, o fato de o líquido não subir? Ou não precisar subir?

No âmbito de uma atividade aberta, de cunho dialógico, os questionamentos podem ser tomados para eventual orientação e reflexão do mediador, e não como um roteiro previamente estabelecido, isto é, como um protocolo rígido a ser aplicado em sala de aula. A pertinência e o encadeamento dos referidos questionamentos dependem da dinâmica estabelecida, bem como, fundamentalmente, do conteúdo das respostas à medida que essas forem se manifestando. $\mathrm{O}$ último item exposto na listagem, por exemplo, somente faz sentido se em resposta ao questionamento antecedente esse tipo de direcionamento se manifestar.

É importante considerar inclusive que, entre as possíveis respostas dos alunos ao fenômeno do canudinho, possa vir à tona a referência à pressão atmosférica. Caso isto ocorra, é relevante estabelecer diálogo que permita compreender se o conceito está sendo aplicado de forma adequada ou se a referência é fragmentada, como pesquisas empíricas costumam apontar. Caso a referência de fato se aproxime da consideração científica atual é importante registrá-la como uma proposta para reflexão em meio a outras que venham a se manifestar, as quais possivelmente devem refletir concepções alternativas. Sugere-se, ainda, que, ao longo do Momento 1, o professor encaminhe discussão sobre aspectos relacionados à natureza do conhecimento científico, tais como, a ciência como tentativa de explicar fenômenos naturais.

Quanto ao questionamento sobre o canudo furado, pretende-se que a pergunta chame a atenção para algo externo, evitando que os alunos focalizem exclusivamente o interior do objeto, como as pesquisas sobre concepções alternativas indicam que o fazem. Mesmo assim, é importante notar que essa pergunta não conduz à concepção científica atualmente aceita. Se tomarmos como base os resultados das mesmas pesquisas é possível a manifestação de respostas do tipo: o ar entra pelo furo e ocupa o espaço que ficaria vazio pelo ato de sugar o ar; nesse caso o líquido não precisa subir.

$\mathrm{O}$ intuito desse primeiro momento é conhecer as concepções sustentadas inicialmente pelos alunos, quer sejam as mesmas adequadas ou não, segundo o ponto de vista científico atual. Adota-se a perspectiva de que essas explicações, mesmo se insatisfatórias, não são erros tolos. As visões iniciais devem ser o ponto de partida para o próprio processo de construção do conhecimento em sala de aula. Busca-se atingir esse objetivo por meio de atividades dialógicas, mediadas, nas quais os alunos exercem papel ativo na formulação de explicações. 
No decorrer da sequência sugerida, propõe-se que os próprios alunos, através da interpretação mediada de fontes primárias, percebam na ciência do passado possibilidades de explicações semelhantes às que a turma sustentou no primeiro momento: sejam elas próximas ao "horror ao vazio", sejam elas possibilidades que recorram à ideia de pressão atmosférica. Ressalvas sobre o caráter não simplista dessas comparações são explicitadas a seguir.

O Apêndice 1 do presente artigo apresenta uma proposta de material apostilado sugerida para que os alunos registrem suas reflexões a partir dos questionamentos propostos para reflexão coletiva. O material é dividido de acordo com os momentos da sequência didática e contém transcrições das fontes primárias.

\section{Momento 1 - Segunda parte}

Em sequência à primeira atividade, propõe-se que os alunos sejam convidados à interpretação diacrônica de trecho de uma fonte primária medieval que traz à tona justamente o "horror ao vácuo". Trata-se de um registro histórico produzido pelo pensador francês Jean Buridan, no séc. XIV, a respeito de um fenômeno de seu interesse:

Quando colocamos a extremidade de um canudo [de junco] na boca e mergulhamos a outra extremidade no vinho [...] sugamos o ar do canudo, atrai-se o vinho para cima, embora ele seja pesado. Isso ocorre porque é necessário que algum corpo sempre venha logo depois do ar que é sugado para cima, para evitar a formação de um vácuo [...] (BURIDAN, Questiones super octo physieorum libros Aristotelis apud MARTINS, 1989, p. 19).

A seguir, sugerem-se questionamentos como possibilidade de orientação a debate em aula. Novamente, o contexto educacional visado é central para definir a pertinência dos mesmos.

- Que fenômeno Buridan estava tentando explicar?

- Este fenômeno se assemelha ao nosso problema inicial?

- A que conclusões chegamos na nossa tentativa de explicar esse acontecimento?

- Qual foi a explicação de Buridan?

- O que podemos notar quando comparamos as nossas explicações às dele? São semelhantes? Diferentes? Por quê?

- Para explicar esse fenômeno, pensamos em algo fora do canudo, algum agente atuando fora do canudo? E, Buridan, como ele pensou?

Essa etapa propõe, portanto, que, em atividade dialógica mediada pelo professor, os alunos reflitam sobre a afirmação realizada por Buridan a respeito do mesmo fenômeno focalizado por eles próprios na Primeira Parte do Momento 1. Sugere, ainda, que confrontem os pensamentos de Buridan aos seus próprios pensamentos.

Os alunos podem identificar que Jean Buridan tratou do mesmo fenômeno, que a utilização de canudos não é recente e que o fenômeno já chamava a atenção dos pesquisadores há 
bastante tempo. O líquido era vinho, não água ou refrigerante, o qual nem existia na época. $\mathrm{O}$ canudo por sua vez era de junco, e não de plástico, material que não existia no século XIV. Para Buridan, se o ar era retirado, o líquido tinha que subir imediatamente para evitar a formação de espaço vazio.

Na apresentação da Primeira Parte do Momento 1, comentamos sobre eventuais respostas mais prováveis dos alunos, tomando como base resultados de pesquisas sobre concepções alternativas. Se considerarmos essas respostas, podemos traçar expectativas sobre o que ocorreria se estudantes, com auxílio do professor, comparassem a explicação de Buridan às suas próprias explicações.

Jean Buridan explicou a subida do líquido pensando em algo interno ao canudo. É provável que boa parte dos estudantes também dirija sua atenção para o interior do canudo. Para Buridan, o líquido subia pelo canudo porque não era aceitável a existência de um espaço vazio. Nas explicações iniciais dos estudantes provavelmente seria preponderante algo semelhante, sinalizando uma visão plenista da natureza: devido à retirada do ar de dentro do canudo, o líquido tenta ocupar o espaço deixado por ele (SOLAZ-PORTOLÈS, 2008).

É relevante destacar a importância de estimular a imaginação dos alunos. De acordo com esse objetivo, propõe-se algo que extrapola a interpretação do documento histórico. Podese solicitar que os alunos se coloquem no lugar de Jean Buridan e respondam ao questionamento sobre o canudo furado: Pensando como Buridan, como explicaríamos a não subida do líquido quando o canudo está furado?

É possível que os alunos percebam certa correspondência entre o que Buridan responderia e o que a própria turma muito provavelmente teria respondido diante do mesmo questionamento: o líquido não sobe porque o ar entra no canudo pelo furo, não havendo espaço vazio que o líquido precise ocupar.

Adicionalmente, é imprescindivel destacar a necessidade de uma postura diacrônica ao longo das atividades com os documentos históricos. A mediação é fundamental para que possam ser notadas diferenças importantes em relação às afirmações de Jean Buridan. No texto escrito por Buridan aparece a afirmação "evitar a formação de um vácuo", que caracteriza a concepção do "horror ao vácuo" da qual o pensador era partidário. Não se espera que uma afirmação formal, contundente, a respeito da impossibilidade do vazio na natureza seja realizada por estudantes do Ensino Médio.

Jean Buridan repercutia uma tradição nesse sentido, um contexto particular e, portanto, distinto do vivenciado pelos estudantes. Buridan manifestou suas observações em contexto científico no qual postura de negação do vazio era paradigmática. Ele não expressou uma opinião espontânea, imediata, sobre o fenômeno do canudinho. Os pensadores do passado estudaram seriamente os problemas físicos, discutindo-os do ponto de vista epistemológico e filosófico. O paralelo com a concepção dos alunos não pode esconder essa complexidade.

Prevista para ter início nessa etapa e continuidade na etapa seguinte da intervenção, $a$ contextualização histórica é fundamental para que esses e outros aspectos sejam percebidos 
pelos próprios alunos. O "horror ao vazio" não foi um “equívoco", uma concepção simples, superada por uma concepção supostamente mais elaborada, correta e com base experimental: a diferença de pressão. Visões de mundo, argumentos teóricos e empíricos foram trazidos à tona nos questionamentos. O próprio experimento de Torricelli e outros subsequentes eram sujeitos a interpretações dissonantes. Não houve uma construção linear do conhecimento, mas sim um movimento complexo de idas e vindas. Trata-se de uma contextualização histórica que não sinalize certos e errados, isto é, que se contraponha a uma perspectiva Whig ${ }^{18}$.

A concepção da Segunda Parte do Momento 1 contempla a presença ativa dos participantes no processo de questionamento e busca de soluções para os problemas, em procedimento dialógico. No Momento 2, fontes primárias são apropriadas como recursos didáticos de forma que o aluno se aproxime do conceito de pressão atmosférica por meio do seu processo de construção histórica.

É importante considerar, no entanto, que ainda no Momento 1 referências à atuação da pressão atmosférica podem se manifestar. Sejam essas referências satisfatórias ou não, é relevante a mediação do professor no sentido de estimular a percepção de que tal "elemento" não aparece nas afirmações de Buridan. Questionamentos nessa direção funcionariam como encadeamento para o Momento 2:

- Se Buridan não cita a pressão atmosférica, quando essa ideia teria surgido?

- Na fala de Buridan, é dado algum indício de que para esse pensador o ar tinha peso? Será que outros pensadores refletiam sobre isso?

- Considerando o peso do ar, explicações diferentes poderiam ser propostas para o problema do canudinho?

\section{Momento 2}

O segundo momento da sequência didática tem como objetivo contribuir com elementos para a compreensão do que vem a ser a pressão atmosférica, por meio do resgate de aspectos do processo de construção histórica desse conceito.

Sugere-se a realização de um experimento acompanhado pela leitura de comentário do filósofo grego Aristóteles (século IV a. C.). Originalmente, o experimento havia sido realizado para demonstrar que o ar tinha também a propriedade da gravidade, assim como os demais elementos sublunares. Nesse experimento, uma vareta é suspensa com uma bexiga cheia em uma extremidade e uma bexiga vazia na outra.

[...] o ar é pesado [...]. A evidência disso é que uma bexiga cheia pesa mais do que quando vazia (ARISTÓTELES, Sobre os Céus apud MARTINS, 1989, p. 24).

Em seguida, sugere-se que o professor traga elementos que deem prosseguimento à contextualização histórica, de modo preceder a utilização didática de recortes de escritos do

18 Uma História Whig procura mostrar os "erros" que atrasaram a evolução da ciência. 
pesquisador Isaac Beeckman, do século XVI. Os seguintes elementos poderiam ser comenta$\operatorname{dos}^{19}$ :

- A conclusão de Aristóteles não foi bem aceita;

- Três séculos depois, o pensador grego Simplício afirmou que havia repetido o experimento sem sucesso. Segundo Simplício, Aristóteles teria se equivocado: ao soprar a bexiga teria inserido umidade em seu interior, causando a diferença de peso;

- As discussões prosseguiram ao longo dos séculos e envolveram contribuições de diversos pensadores;

- No século XVI, o pensador Isaac Beeckman trouxe elementos que contribuíram para que a visão de que o ar tinha peso e exercia pressão fosse cada vez mais aceita. Esse novo fator podia levar a uma reinterpretação de fenômenos antes atribuídos ao "horror ao vazio";

- Isaac Beeckman partiu das ideias de Simon Stevin, que, em seus estudos, havia concluído que corpos submersos na água eram pressionados por todos os lados. Então, partindo do que o seu mestre havia dito sobre a água, Beeckman realizou, por analogia, afirmações sobre $o$ ar.

Finalizada a contextualização introdutória, sugere-se a leitura compartilhada do seguinte trecho escrito por Isaac Beeckman:

[...] o ar é pesado [...] ele nos pressiona de todos os lados de um modo uniforme. [...]. As coisas se precipitam para um espaço vazio com grande força, por causa da imensa altura do ar acima (BEECKMAN, Mathematico-physicarum meditationem apud MARTINS, 1989, p. 25).

Para a reflexão compartilhada a respeito desse registro histórico, propõem-se algumas questões:

- Retomando o Momento 1, o que Jean Buridan pareceu pensar acerca do peso do $a r ?$

- O que Beeckman quis dizer quando afirmou que "o ar nos pressiona de todos os lados"? Podemos sentir esse efeito?

- Observando a afirmação de Beeckman, que ação exerce o ar sobre as coisas de modo que elas precipitem para um espaço vazio?

- Vamos imaginar a superfície do nosso copo com água... Segundo Beeckman, o que haveria acima dessa superfície? Esse possível fator inicial, isto é, esse pressuposto teórico era considerado por Buridan na sua explicação para o fenômeno do canudinho?

- Será que Isaac Beeckman discordaria de Jean Buridan sobre o problema do canudinho?

19 Os referidos elementos se baseiam nos trabalhos citados e recomendados para consulta. 
Novamente, a atividade dialógica mediada pelo professor implica o engajamento dos estudantes em tentativa de solucionar problemas relacionados à temática. Questionam-se possíveis consequências para a interpretação do fenômeno do canudinho decorrentes de eventual aceitação da afirmação de Beeckman.

Trata-se de um processo de construção coletiva de conhecimento em sala de aula, o qual pode ser acompanhado de discussões contextualizadas sobre questões relacionadas à Natureza da Ciência, tais como: a possibilidade de desacordo entre os pesquisadores, a provisoriedade da ciência e a dependência da observação em relação a pressupostos teóricos (MCCOMAS; ALMAZROA; CLOUGH, 1998; CLOUGH; OLSON, 2008; MCCOMAS, 2008) ${ }^{20}$.

\section{Momento 3}

Em prosseguimento da sequência didática, o Momento 3 prevê como ponto de partida para problematização a utilização de livros didáticos de Física usualmente adotados no Ensino Médio. Em geral, os livros reforçam meramente os produtos da ciência, apresentam fatos históricos isolados, fora de contexto ou simplesmente cientistas em posição de descobridores do funcionamento da natureza (GIL PÉREZ et al., 2001; MARTINS, 2006).

Não há significativa variação na forma como o tópico "pressão atmosférica" costuma aparecer em livros didáticos recentes de Física. Assim, o professor muito possivelmente irá se defrontar com certos aspectos no livro de que dispõe ${ }^{21}$. O conceito de pressão atmosférica é enunciado de forma pronta, em breve referência que não faz jus ao desenvolvimento histórico. Torricelli teria descoberto esse fenômeno devido à realização do seu experimento mais famoso. Afirma-se que ele demonstrou a existência da pressão atmosférica e calculou seu valor (MÁXIMO; ALVARENGA, 2006, p. 238). O chamado “experimento de Torricelli” é apresentado como uma "medida da pressão atmosférica" (NICOLAU; TORRES; PENTEADO, 2012). Um tubo de vidro foi totalmente preenchido com mercúrio e emborcado em um recipiente contendo também mercúrio. No nível do mar, a coluna de mercúrio dentro do tubo elevou-se a aproximadamente $76 \mathrm{~cm}$ acima do nível do mercúrio no recipiente: "concluiu corretamente que essa coluna de mercúrio era equilibrada pela pressão atmosférica exercida na superfície livre da cuba, ao nível do mar, onde realizou o experimento" (GASPAR, 2011, p. 333). Registra-se o termo "vácuo Torricelliano" em referência à região do alto do tubo invertido (NICOLAU; TORRES; PENTEADO, 2012).

As breves referências sintetizadas no parágrafo anterior implicam distorções e lacunas compartilhadas por materiais didáticos no que diz respeito ao conteúdo de Física em questão e

\footnotetext{
${ }^{20}$ Essa referência não implica perder de vista ressalvas importantes. Não há uma visão única adequada sobre a natureza da ciência, sendo a mesma complexa e dinâmica (BAGDONAS; ZANETIC; GURGEL, 2012; MONTEIRO; MARTINS, 2015). Por outro lado, posturas extremas como o empirismo-indutivismo deveriam ser problematizadas (BAGDONAS; SILVA, 2013).

21 O material apostilado, apresentado no Apêndice 1, traz, como exemplo, recortes de um livro didático de Física (NICOLAU; TORRES PENTEADO, 2012).
} 
sua história ${ }^{22}$. Transmitem concepções simplistas de descoberta isolada e reforçam visões empiristas-indutivistas da ciência.

Não costuma haver (nos livros didáticos) informação sobre os antecedentes, bem como sobre o contexto das investigações de Torricelli, que se inseria na controvérsia sobre a existência do vazio. Não transparece a construção coletiva do conhecimento científico e deixa-se escapar a oportunidade de apresentar a ciência como atividade humana. A profícua troca de correspondência entre pesquisadores na época é omitida. Não costumam ser citadas contribuições de outros personagens e problemas cotidianos em discussão na época (como o funcionamento de bombas d'água), que permitiriam visualizar de forma contextualizada o próprio experimento de Torricelli.

A referência exclusiva a Evangelista Torricelli sugere que ele teria sido o primeiro a evidenciar a influência da pressão atmosférica nos fenômenos no dia a dia. Parece que, de repente, com a intenção de medi-la, Torricelli fez aquela montagem específica e (sem justificativa) resolveu usar mercúrio, e não água, embora essa certamente fosse mais acessível.

São omitidos nos livros vários aspectos relevantes: o experimento do tubo com água, realizado anteriormente por outros pesquisadores, no contexto dos debates sobre o vazio; as motivações de Torricelli decorrentes do engajamento na discussão sobre a possibilidade do vazio; sua argumentação baseada em evidências empíricas a respeito do que havia na porção superior do tubo; as dificuldades enfrentadas, a hesitação e a cautela de Torricelli ao sustentar uma concepção dissidente sobre a sustentação da coluna de mercúrio (já que o "horror ao vazio" preponderava).

Interpretações divergentes sobre o fenômeno da sustentação da coluna de mercúrio não são citadas, de modo que transparece de modo equivocado a plena uniformidade de ideias na comunidade científica da época. Parece que não havia uma controvérsia em questão e que as conclusões de Torricelli foram simplesmente aplaudidas. Registra-se o espaço vazio no alto do tubo do mercúrio como se este fosse evidente e incontestável. É distorcida a motivação de Torricelli: o debate sobre a existência do vazio e a busca de explicação para a sustentação da coluna de líquido em experimentos com tubos invertidos (inicialmente contendo água e depois mercúrio, possivelmente por sugestão de Galileu). Negligencia-se a oportunidade de discutir sobre o abalo à tradição do "horror ao vácuo" como uma ruptura expressiva, polêmica, sendo essa uma característica importante da ciência.

O Momento 3 da sequência didática propõe que o professor, a partir de eventuais lacunas no livro didático de que dispõe, o utilize em sala de aula de forma a explorá-las ${ }^{23}$. Sugere-

\footnotetext{
22 Os comentários a seguir se baseiam em trabalhos oriundos de pesquisas em História da Ciência e documentos já citados, os quais são recomendados para aprofundamento.

23 Recomenda-se aos professores a consulta a material de apoio já citado (OLIVEIRA, 2013). O professor pode desejar, eventualmente, contemplar outros aspectos na discussão, encontrando embasamento no referido material: Como será que Torricelli chegou a propor um experimento tão específico? Por que ele não usou água, já que o acesso a esse líquido devia ser mais fácil?
} 
se problematização com base em questionamentos que extrapolam o conteúdo usual do material didático:

- O que o livro didático nos leva a pensar sobre a intenção de Torricelli?

- Será que a intenção de Torricelli foi realmente medir a pressão atmosférica? Será que era isso que ele estava tentando resolver?

- O “vácuo" ("vazio" ou "vácuo torricelliano"), que o livro cita, era mesmo aceito na época? Ninguém mais pensava no "horror ao vazio"? O próprio Torricelli não tinha nenhuma dúvida?

- Por meio do experimento de Torricelli é mesmo possível ver/observar que a sustentação do mercúrio se deve a algo externo (pressão)? O experimento mostra esse resultado?

- Será que Torricelli teve alguma dificuldade para sua conclusão? Ele chegou mesmo a uma conclusão final?

- Ao observar o experimento era possível "ver" a pressão atmosférica atuando?

- Voltando a Jean Buridan, ele usou a ideia de pressão atmosférica no caso do canudinho?

- De acordo com a ideia de pressão atmosférica, o fenômeno do canudinho poderia ser interpretado de outra maneira, diferente da sugerida por Buridan?

- O que será que as pessoas pensavam sobre isso na época de Torricelli?

Os referidos questionamentos materializam o intuito de que o aluno desenvolva o pensamento crítico acerca do conhecimento científico e seu desenvolvimento. Propõe-se refletir de forma dialógica sobre aspectos tomados como verdade pelos livros, como o citado "vácuo torricelliano". O papel do professor-mediador é fundamental no sentido de conduzir ao resgate de elementos já contemplados nos momentos anteriores, como as afirmações de Heron e Buridan sobre o "horror ao vazio".

Algumas reflexões sugeridas buscam estimular a imaginação dos estudantes, levantando suspeitas, por exemplo, de que faltam elementos na descrição do experimento de Torricelli. Em boa parte, esses elementos ficam sem resposta no Momento 3 e serão resgatados na etapa posterior da sequência didática, com a utilização de uma entrevista fictícia elaborada a partir de recortes de escritos do próprio Torricelli.

Outro aspecto fundamental contemplado pelos questionamentos remete a um eventual entrelaçamento entre a ideia de pressão atmosférica e o fenômeno do canudinho, abordado no início da sequência didática.

\section{Momento 4}

A sequência didática contempla, no Momento 4, a utilização de uma entrevista fictícia com o pesquisador Evangelista Torricelli (ver Apêndice 2).

Em 1644, Evangelista Torricelli descreveu suas pesquisas em carta ao estudioso Michelangelo Ricci (MAGIE, 1969, p. 70-73). O processo de tradução da carta levou em conta o tratamento diacrônico dos escritos, reflexões sobre o contexto histórico e científico, a visão de 
ciência e a nomenclatura científica coetânea. Entretanto, mesmo em vernáculo, as características da carta em termos de conteúdo e formulação discursiva dificultam sua utilização na forma integral no contexto educacional básico (BATISTA, 20014; BATISTA; DRUMMOND; FREITAS, 2015).

Uma possibilidade de lidar com esses obstáculos é a utilização de recortes da fonte primária de modo que "tais trechos venham entremeados por explicações e esclarecimentos para auxiliar sua interpretação" (FORATO, 2009, p. 105). Adotou-se essa perspectiva na composição de uma entrevista fictícia, na qual "perguntas" elaboradas trazem à tona as intencionalidades de Evangelista Torricelli em "respostas" que são trechos originais escritos pelo pesquisador (BATISTA, 2014; BATISTA; DRUMMOND; FREITAS, 2015) ${ }^{24}$.

Sugere-se uma leitura compartilhada do material em sala de aula, na qual diferentes duplas de alunos podem representar o jornalista e Torricelli em cada conjunto pergunta-resposta. Atuando como mediador, o professor pode encaminhar discussões que englobam elementos contextuais do processo de construção histórica do conhecimento científico em foco. Algumas questões são sugeridas para reflexão de forma a estimular a criticidade e imaginação dos alunos, bem como a familiarização com o papel investigativo/interpretativo da História da Ciência:

- A intenção de Torricelli era simplesmente medir a pressão atmosférica? Era isso que ele estava tentando resolver?

- Será que outras pessoas pensavam sobre o problema focalizado por Torricelli?

- Torricelli teve alguma dificuldade? Ele chegou mesmo a uma conclusão final?

- A figura no livro mostra um espaço aparentemente "vazio" no alto do tubo do experimento de Torricelli. O livro se refere ao "vácuo torricelliano". Será que estava realmente vazio na visão de Torricelli? O fato de Torricelli argumentar e dar atenção a esse assunto indica que essa era uma certeza na época?

- O que, na opinião de Torricelli, sustentaria a coluna de mercúrio?

- Há uma relação entre a afirmação de Beeckman e o experimento de Torricelli?

\footnotetext{
${ }^{24}$ Um dos autores do presente trabalho participou da elaboração da entrevista, a qual compõe a quinta edição de um jornal histórico sugerido para aplicação no Ensino Médio (BATISTA; DRUMMOND; FREITAS, 2015). As demais edições do jornal são indicadas para consulta pelo professor e podem ser utilizadas em sala de aula para uma contextualização histórica mais efetiva, dependendo da disponibilidade de tempo (BATISTA, 2014). A Edição I abrange as discussões na Antiguidade envolvendo Aristóteles, eleatas e atomistas quanto à existência do vazio. A Edição II remete a discussões da Era Cristã e Idade Média. Evidencia a forte negação do vazio, com argumentos que retomam a influência aristotélica na interpretação de elementos do cotidiano (como o funcionamento de um sifão e de um canudo para sorver líquidos), bem como articula diversos experimentos imaginários. A controvérsia se faz presente na medida em que alguns pensadores sustentam a possibilidade do vazio. As Edições III e IV trazem aspectos dessas discussões na Revolução Científica, quando o "horror ao vazio" é uma tradição marcante. No entanto, na época, a defesa do vazio ganha evidência com a retomada de argumentos atomistas e novos argumentos surgem em meio à visão de que o ar possui peso e exerce pressão. As edições ressaltam a forte cooperação, trocas de informações entre os pensadores e propostas de vários experimentos para discutir sobre o vazio. Esses seriam antecedentes e inspiração para o experimento realizado por Evangelista Torricelli.
} 
- Mesmo considerando o peso do ar e sua atuação sobre o mercúrio, ainda assim era possivel sugerir que o espaço vazio influenciava no equilíbrio da coluna de mercúrio? Torricelli afirmou que era possível excluir definitivamente outras causas, ficando apenas com a ação do peso do ar?

Ao longo da entrevista é possível perceber alguns aspectos interessantes para reflexão coletiva. Torricelli tem dificuldades quanto a garantir que a parte superior do tubo está vazia e se empenha em argumentar a esse respeito. Torricelli afirma que a causa da sustentação da coluna de mercúrio é a pressão do ar sobre a superfície do líquido. No entanto, ao realizar essa afirmação, o pesquisador transmite a impressão de ser partidário de uma interpretação dissidente.

Além disso, Torricelli afirma que gostaria de estudar experimentalmente mudanças na atmosfera, mas admite dificuldades e reconhece que não tem uma conclusão final. Há questões que ele não consegue explicar. Manifesta a intenção de entender o comportamento da atmosfera, mas deixa transparecer que o caminho dessa investigação não é simples e parece não resultar no que havia previsto. Por outro lado, Torricelli não parece desanimado e sim estimulado pelo desafio.

Assim, detalhes que trazem à tona a hesitação e a dúvida, ressaltando o caráter humano da pesquisa científica, podem ser contemplados na discussão da entrevista. Podem ser destacados elementos tais como: a compreensão de diferentes interpretações para a sustentação da coluna de mercúrio; a intencionalidade do pesquisador ao expressar sua interpretação específica; qual seria a mais tradicional e qual seria a divergente; a possibilidade de existência de diferentes explicações para um mesmo fenômeno natural, sendo esse um importante aspecto da natureza do conhecimento científico.

Particularmente, podem ser abordados aspectos que fogem à afirmação simplista de que Torricelli "descobriu” a pressão atmosférica como uma importante revelação em seu famoso experimento e a mediu.

Contrariamente, pode colaborar para a compreensão desse conceito a iniciativa de invocar o seu desenvolvimento como resposta a questionamentos realizados por pensadores do passado. O uso de canudos para sorver líquidos e o funcionamento de sifões foram questões que inquietaram os pesquisadores envolvidos na controvérsia sobre a existência do vazio. Foi no contexto de oposição ao "horror ao vazio" (e não como tentativa de medir a pressão atmosférica) que Torricelli realizou seu experimento, tal como ele próprio reconheceu.

Para a finalização da proposta de sequência didática, sugere-se a retomada de elementos que vieram à tona nos momentos anteriores.

Pode-se encaminhar uma síntese de considerações sobre a ciência: a mutabilidade do conhecimento e, ao mesmo tempo, a sua relativa estabilidade; a construção coletiva e a dependência da observação em relação a pressupostos teóricos. Espera-se que, com a mediação do professor, os estudantes possam resgatar elementos de contextualização para esses tópicos a 
partir dos episódios históricos abordados e demonstrem certo afastamento em relação a visões ingênuas.

No que diz respeito à compreensão dos conteúdos científicos, sugere-se o retorno ao questionamento inicial sobre o fenômeno físico da subida de um líquido por um canudo. Nesse caso, tendo como ponto de partida a atuação da pressão atmosférica pode-se ensaiar uma nova tentativa de explicação: tomando como base a consideração de que o ar tem peso e exerce pressão, como poderia ser explicada a subida do líquido através do canudo quando tomamos suco/refrigerante?

\section{Considerações finais}

Elementos relacionados ao processo de construção histórica da ciência podem ser discutidos ao longo das atividades interpretativas sobre os documentos históricos (em recortes, utilizados na composição de narrativa, como a entrevista fictícia ou em excertos de textos originais).

O desenvolvimento do conceito de pressão atmosférica se insere na discussão sobre a existência do vazio, sendo este um elemento contextual que permite compreender melhor o experimento de Torricelli, trazido usualmente de forma simplista em livros didáticos.

A perspectiva de utilização didática de fontes primárias permite atuar em lacunas observadas nesses materiais, trazendo justamente aquilo que eles não costumam conter: o processo de desenvolvimento e justificativa para os produtos da ciência neles apresentados.

O enfoque pautado em atividades dialógicas, por sua vez, estabelece a construção coletiva do conhecimento em sala de aula, em processo no qual professor e alunos se inserem como protagonistas 25 .

Particularmente, a sequência didática proposta é iniciada a partir da discussão de um fenômeno cotidiano. De acordo com pesquisas empíricas, o resultado dessa primeira etapa deve se configurar como um repertório de explicações com base em concepções alternativas, que de certa forma se aproximam do "horror ao vazio", e eventuais explicações nas quais o conceito de pressão atmosférica aparece de modo mais ou menos formal.

A "viagem no tempo" oportunizada pela contextualização histórica e pelo contato com fontes primárias permite perceber que pesquisadores do passado também se dedicaram a discutir o mesmo fenômeno e outros de natureza equivalente. Essas discussões transcorreram de forma complexa, segundo bases epistemológicas e filosóficas específicas do "horror ao vácuo", o qual não deve ser tomado como um equívoco do passado. A proposta permite, ainda, que os próprios alunos reflitam sobre semelhanças e diferenças entre suas propostas e visões sustentadas por pesquisadores de outras épocas. Considera-se que esse processo pode colaborar para o entendimento do conceito físico de pressão atmosférica, de forma que o mesmo venha a

\footnotetext{
25 Nesse sentido, desafios relacionados à formação docente para a utilização de abordagens histórico-filosóficas demandam atenção (HÖTTECKE; SILVA, 2010; FORATO; MARTINS; PIETROCOLA, 2012).
} 
ser utilizado pelos estudantes em uma reinterpretação ou estruturação mais adequada da explicação prévia para o fenômeno físico inicialmente submetido a problematização.

\section{Referências}

BAGDONAS, A.; ZANETIC, J.; GURGEL, I. Críticas à visão consensual da Natureza da Ciência e a ausência de controvérsias na Educação Científica. In: ENCONTRO NACIONAL DE PESQUISA EM ENSINO DE FÍSICA, 14, 2012, Maresias. Anais... SBF, 2012. Disponível em: $<$ http://www.sbf1.sbfisica.org.br/eventos/epef/xiv/sys/resumos/T0160-1.pdf >. Acesso em: 7 set. 2015.

BAGDONAS, A.; SILVA, C. C. Controvérsias sobre a natureza da ciência na educação científica. In: SILVA, C. C.; PRESTES, M. E. B (Eds.). Aprendendo ciência e sobre sua natureza: abordagens históricas e filosóficas. São Carlos: Tipographia, 2013. p. 213-224.

BATISTA, R. P.; MOHR, A.; FERRARI, N. A análise da história da ciência em livros didáticos do ensino fundamental em Santa Catarina. In: ENCONTRO NACIONAL DE PESQUISA EM EDUCAÇÃO EM CIÊNCIAS, 6, 2007, Florianópolis, SC. Anais... ABRAPEC, 2007. Disponível em: <http://www.nutes.ufrj.br/abrapec/vienpec/CR2/p380.pdf>. Acesso em: 8 jul. 2014.

BATISTA, G. L. F. Fontes Primárias da História do Vácuo e da Pressão Atmosférica na Sala de Aula: cartas e jornais históricos em articulação com o livro-texto do Ensino Médio. 2014. Dissertação (Mestrado) - UFRN. Disponível em: <http://repositorio.ufrn.br:8080/ jspui/handle/123456789/16115 >. Acesso em: 7 set. 2015.

BATISTA, G. L. F.; DRUMMOND, J. M. H. F.; FREITAS, D. B. Fontes primárias no ensino de física: considerações e exemplos de propostas. Caderno Brasileiro de Ensino de Física, Florianópolis, v. 32, n. 3, p. 663-702, dez. 2015. Disponível em: <https://periodicos.ufsc.br/index.php/fisica/article/view/2175-7941.2015v32n3p663>. Acesso em: 25 mar. 2016.

BEZERRA, E. V. L. Análise de propostas didáticas de história e filosofia da ciência para o ensino de física. 2014. Dissertação (Mestrado) - UFPR. Disponível em: <http://www.ppgecm.ufpr.br/Dissertações/040_EvaldoVictorLimaBezerra.pdf>. Acesso em: 7 mai. 2015.

BOAS, A. V. et al. História da Ciência e Natureza da Ciência: debates e consensos. Caderno Brasileiro de Ensino de Física, Florianópolis, v. 30, n. 2, p. 287-322, ago. 2013. Disponível em: $\quad<$ https://periodicos.ufsc.br/index.php/fisica/article/view/2175-7941.2013v30n2p287>. Acesso em: 17 mai. 2015.

BOSS, S. L. B.; SOUZA FILHO, M. P.; CALUZI, J. J. Fontes Primárias e Aprendizagem Significativa: Aquisição de subsunçores para aprendizagem do conceito de carga elétrica. In: EN- 
CONTRO NACIONAL DE PESQUISA EM EDUCAÇÃO EM CIÊNCIAS, 7, 2009, Florianópolis, SC. Anais... ABRAPEC. 2009. Disponível em: <http://posgrad.fae.ufmg.br/pos$\mathrm{grad} / \mathrm{viienpec/pdfs/1717.pdf}>$. Acesso em: 17 mai. 2015.

Traduções de Fonte Primária - Algumas Dificuldades Quanto à Leitura e o Entendimento. In: ENCONTRO NACIONAL DE PESQUISA EM EDUCAÇÃO EM CIÊNCIAS, 8, 2011, Campinas, SP. Anais... ABRAPEC, 2011. Disponível em: <http://www.nutes.ufrj.br/abrapec/viiienpec/resumos/R0441-1.pdf >. Acesso em: 17 mai. 2015.

BOSS, S. L. B. Tradução comentada de artigos de Stephen Gray (1666-1736) e reprodução de experimentos históricos com materiais acessíveis - subsídios para o ensino de eletricidade. 1011. Tese (Doutorado) - UNESP. Disponível em: <http://repositorio.unesp.br/handle/11449/102009>. Acesso em: 26 mar. 2016.

Considerações sobre a produção e o uso de material histórico em sala de aula: dificuldades de leitura e entendimento de traduções de fontes primárias. In: CAMARGO et al. (Org.). Controvérsias na Pesquisa em Ensino de Física. São Paulo: Editora Livraria da Física, 2014. p. 161-176.

BRASIL, Ministério da Educação - MEC, Secretaria de Educação Média e Tecnológica - SEMTEC. Parâmetros Curriculares Nacionais para o Ensino Médio. Brasília: MEC/SEMTEC, 2000.

BRICCIA, V.; CARVALHO, A. M. P. Visões sobre a Natureza da Ciência construídas a partir do uso de um texto histórico na escola média. Revista Electrónica de Enseñanza de las ciencias, v. 10, n. 1, p. 1-22, 2011. Disponível em: <http://reec.uvigo.es/volumenes/volumen10/ART1_Vol10_N1.pdf >. Acesso em: 17 mai. 2015.

BUENO, M. C. F.; PACCA, J. L. A. Combinando a leitura de originais da ciência com outras atividades para construir o conhecimento na sala de aula. In: ENCONTRO NACIONAL DE PESQUISA EM EDUCAÇÃO EM CIÊNCIAS, 7, 2009, Florianópolis, SC. Anais... ABRAPEC. 2009. Disponível em: <http://posgrad.fae.ufmg.br/posgrad/viienpec/pdfs/927.pdf>. Acesso em: 17 mai. 2015.

BUTY, C; TIBERGHIEN, A; MARÉCHAL, J-F. Learning hypotheses and an associated tool to design and to analyse teaching-learning sequences. International Journal of Science Education, London, v. 26, n. 5, p. 579-604, 2004. Disponível em: <http://dx.doi.org/10.1080/09500690310001614735>. Acesso em: 8 set. 2015.

CAIMI, F. E. Fontes históricas na sala de aula: Uma possibilidade de produção de conhecimento histórico escolar? Anos 90, Porto Alegre, v. 15, n. 28, p. 129-150, dez. 2008. Disponível em: <http://seer.ufrgs.br/anos90/article/view/7963>. Acesso em: 17 mai. 2015. 
CARVALHO, A. M. P. et al. A história da ciência, a psicogênese e a resolução de problemas na construção do conhecimento em sala de aula. Revista da Faculdade de Educação, São Paulo, v. 19, n. 2, p. 245-256, 1993. Disponível em: <http://www.revistas.usp.br/rfe/article/view/33529>. Acesso em: 25 mar. 2016.

CLOUGH, M. P.; OLSON, J. K. Teaching and assessing the nature of science: an introduction. Science \& Education, Dordrecht, n. 17, p. 143-145, 2008. Disponível em: <http://link.springer.com/article/10.1007/s11191-007-9083-9>. Acesso em: 25 mar. 2016.

COELHO, S. M.; NUNES, A. D. Análise de um texto do século XVII, “A grande experiência de equilíbrio dos líquidos", de Pascal: aspectos do método experimental e reflexões didáticas. Revista Brasileira de Ensino de Física, São Paulo, v. 1, n. 14, p. 24-28, 1992. Disponível em: <http://www.sbfisica.org.br/rbef/pdf/vol14a05.pdf>. Acesso em: 25 mar. 2016.

DION, S. M.; LOURES, M. V. R. O debate realismo/antirrealismo em situações de ensino de física, à luz da interface entre história e filosofia da ciência. In: SILVA, C. C.; PRESTES, M. E. B. (Org.) Aprendendo ciência e sobre sua natureza: abordagens históricas e filosóficas. São Carlos: Tipographia, 2013. p. 193-208.

FONSECA, D. S.; DRUMMOND, J. M. H. F.; OLIVEIRA, W. C. Investigando o uso didático de fontes primárias da história do vácuo e da pressão atmosférica. In: ENCONTRO NACIONAL DE PESQUISA EM ENSINO DE FÍSICA, 16, 2016, Natal, RN. Anais... SBF, 2016. Disponível em: <http://www1.sbfisica.org.br/eventos/enf/2016/sys/resumos/T0745-1.pdf>. Acesso em: 10 set. 2016.

FONSECA, D. S.; OLIVEIRA, W. C.; DRUMMOND, J. M. H. F. Investigando o ensino de natureza da ciência em minicurso para estudantes do ensino médio. In: ENCONTRO NACIONAL DE PESQUISA EM ENSINO DE FÍSICA, 16, 2016, Natal, RN. Anais... SBF, 2016. Disponível em: <http://www1.sbfisica.org.br/eventos/enf/2016/sys/resumos/T0745-2.pdf>. Acesso em: 10 set. 2016.

FORATO, T. C. M. A natureza da ciência como saber escolar: um estudo de caso a partir da história da luz. 2009. Tese (Doutorado) - USP. Disponível em: <http://www.teses.usp.br/teses/disponiveis/48/48134/tde-24092009-130728/pt-br.php>. Acesso em: 26 mar. 2016.

FORATO, T. C. M.; MARTINS, R. A.; PIETROCOLA, M. Historiografia e Natureza da Ciência na sala de aula. Caderno Brasileiro de Ensino de Física, Florianópolis, v. 28, n. 1, p. 27 59, abr. 2011. Disponível em: <https://periodicos.ufsc.br/index.php/fisica/article/view/21757941.2011v28n1p27>. Acesso em: 17 mai. 2015.

Enfrentando obstáculos na transposição didática da história da ciência para a sala de aula. In: PEDUZZI, L. O. Q.; MARTINS, A. F. P., FERREIRA, J. M. H. (Org.). Temas de história e filosofia da ciência no ensino. Natal: EDUFRN, 2012. cap. 5, p. 123-154. 
GASPAR, A. Física. São Paulo: Editora Ática, 2011. Volume único.

GIL PÉREZ, D. et al. Para uma imagem não deformada do trabalho científico. Ciência \& Educação, Bauru, v. 7, n. 2, p. 125-153, 2001. Disponível em: <http://www.scielo.br/pdf/ciedu/v7n2/01.pdf>. Acesso em: 17 mai. 2015.

GRANT, E. Much ado about nothing: theories of space and vacuum from the Middle Ages to the Scientific Revolution. Cambridge: Cambridge University Press, 1981.

GUERRA, A. A identidade e o diálogo como possibilidade de superação da controvérsia entre educadores e historiadores da ciência. In: CAMARGO et al. (Org.). Controvérsias na Pesquisa em Ensino de Física. São Paulo: Livraria da Física, 2014. cap. 6, p. 129-142

HÖTTECKE, D.; SILVA, C. C. Why implementing History and Philosophy in School Science Education is a challenge: an analysis of obstacles. Science \& Education, Dordrecht, n. 20, p. 293-316, 2010. Disponível em: <http://link.springer.com/article/10.1007/s11191-010-9285-4>. Acesso em: 15 mai. 2015.

LEDERMAN, N. G. Nature of science: past, present and future. In: ABELL, S.K.; LEDERMAN, N. G. (Eds.). Handbook of Research on Science Education. Mahwah, New Jersey: Lawrence Erlbaum Publishers, 2007. cap. 28. p. 831-880.

Nature of scientific knowledge and scientific inquiry: building instructional capacity through professional development. In: FRASER, B. J.; TOBIN, K. J.; MCROBBIE, C. (Eds.). Second International Handbook of Science Education. v. 1. Dordrecht, London: Springer, 2012. p. 335-360.

LONGUINI, M. D.; NARDI, R. Origens históricas e considerações acerca do conceito de pressão atmosférica. Caderno Brasileiro de Ensino de Física, Florianópolis, v. 19, n. 1, p. 67-78, abr. 2002. Disponível em: <https://periodicos.ufsc.br/index.php/fisica/article/view/9295>. Acesso em: 17 mai. 2015.

. Como age a pressão atmosférica? Algumas situações-problema tendo como base a história da ciência e pesquisas na área. Caderno Brasileiro de Ensino de Física, Florianópolis, v. 26, n. 1, p. 7-23, Abr. 2009. Disponível em: <https://periodicos.ufsc.br/index.php/fisica/article/view/2175-7941.2009v26n1p7>. Acesso em: 17 mai. 2015.

MAGIE, W. F. A source book in Physics. Cambridge, MA: Harvard University Press, 1969.

MARTINS, A. F. P. História e filosofia da ciência no ensino: Há muitas pedras nesse caminho.

Caderno Brasileiro de Ensino de Física, Florianópolis, v. 24, n. 1, p. 112-131, abr. 2007. Disponível em: <https://periodicos.ufsc.br/index.php/fisica/article/view/6056>. Acesso em: 25 mar. 2016. 
MARTINS, R. A. O vácuo e a pressão atmosférica, da antiguidade a Pascal. Caderno de História e Filosofia da Ciência, Campinas, série 2, n. Especial, p. 9-48, 1989.

Introdução. A história das ciências e seus usos na educação. In: SILVA, C. C. (org.).

Estudos de história e filosofia das ciências: subsídios para aplicação no ensino. São Paulo: Livraria da Física, 2006. p. xxi-xxxiv.

MATTHEWS, M. R. Science teaching: the role of History and Philosophy of Science. New York, London: Routledge, 1994.

História, Filosofia e Ensino de Ciências: a tendência atual de reaproximação. Caderno Catarinense de Ensino de Física, Florianópolis, v. 12, n. 3, p. 164-214, 1995. Disponível em: <https://periodicos.ufsc.br/index.php/fisica/article/view/7084>. Acesso em: 25 mar. 2016.

MÁXIMO, A. R. L.; ALVARENGA, B. Física. São Paulo: Editora Scipione, 2006. v. 1.

MCCOMAS, W. F.; AlMAZROA, H.; CLOUGH, M. The nature of science in science education: an introduction. Science \& Education, Dordrecht, n. 7, p. 511-532, 1998. Disponível em: $<$ http://link.springer.com/article/10.1023/A:1008642510402>. Acesso em: 25 mar. 2016.

MCCOMAS, W. F. Seeking historical examples to illustrate key aspects of the nature of science. Science \& Education, Dordrecht, n. 17, p. 249-263, 2008. Disponível em: <http://link.springer.com/article/10.1007/s11191-007-9081-y>. Acesso em: 25 mar. 2016.

MELLADO, V.; CARRACEDO, D. Contribuciones de la filosofía de la ciencia a la didáctica de las ciencias. Enseñanza de las ciencias, v.11, n. 3, p. 331-339, 1993. Disponível em: $<$ http://www.raco.cat/index.php/ensenanza/article/viewFile/21304/93273>. Acesso em: 19 jun. 2015.

MÉHEUT, M.; PSILLOS, D. Teaching-learning sequences: aims and tools for Science education research. International Journal of Science Education, London, v. 26, n. 5, p. 515-535, 2004. Disponível em: <http://dx.doi.org/10.1080/09500690310001614762>. Acesso em: 8 set. 2016.

MONTEIRO, M. M.; MARTINS, A. F. P. História da Ciência na sala de aula: uma sequência didática sobre o conceito de inércia. Revista Brasileira de Ensino de Física, São Paulo, v. 37 , n. 4, p. 4501-1-4501-9, 2015. Disponível em: <http://www.scielo.br/pdf/rbef/v37n4/01024744-rbef-37-4-4501.pdf>. Acesso em: 19 jun. 2015.

NEVES, M. C. D. A História da ciência no ensino de física. Ciência \& Educação, Bauru, v. 5, n. 1, p. 73-81, 1998. Disponível em: <http://www.scielo.br/pdf/ciedu/v5n1/a07v5n1.pdf>. Acesso em: 3 jul. 2015.

NICÁCIO, J. D. S. Formação docente para a inserção da História e Filosofia da Ciência no Ensino: textos histórico-pedagógicos em discussão. 2015. Dissertação (Mestrado) - UFRN. 
Disponível em: <https://repositorio.ufrn.br/jspui/bitstream/123456789/20296/1/JoseDiogoDosSantosNicacio_DISSERT.pdf>. Acesso em: 17 mai. 2015.

NICOLAU, G. F.; TORRES, C. M. A.; PENTEADO, P. C. M. Física. São Paulo: Editora Moderna, 2012.

OLIVEIRA, W. C. Ensinando sobre a Natureza da Ciência: uma abordagem explícita e contextualizada a partir da História do Vácuo. 2013. Dissertação (Mestrado) - UFRN. Disponível em: <http://repositorio.ufrn.br:8080/jspui/handle/123456789/16101>. Acesso em: 17 mai. 2015.

OLIVEIRA, W. C.; DRUMMOND, J. M. H. F. Refletindo sobre desafios à inserção didática da história e filosofia da ciência em oficina de formação docente. Alexandria, Revista de Educação em Ciência e Tecnologia, Florianópolis, v. 8, n. 3, p. 151-179, 2015. Disponível em: <https://periodicos.ufsc.br/index.php/alexandria/article/view/1982-5153.2015v8n3p151>. Acesso em: 17 mar. 2015.

PAGLIARINI, C. R.; SILVA, C. C. A Estrutura dos Mitos Históricos nos Livros de Física. In: ENCONTRO DE PESQUISA EM ENSINO DE FÍSICA, 10, 2006, Londrina, PR. Anais... SBF, 2006. Disponível em: <http://www.ifsc.usp.br/ cibelle/arquivos/T0124-1.pdf>. Acesso em: 8 jul. 2014.

PEDUZZI, L. O. Q. Sobre a utilização didática da História da Ciência. In: PIETROCOLA, M. (Org.) Ensino de Física: conteúdo, metodologia e epistemologia numa concepção integradora. Florianópolis: Ed. da UFSC, 2001. cap. 7. p. 151-170.

Evolução dos Conceitos da Física. Florianópolis: Ed. da UFSC, 2011.

PENA, F. L. A., TEIXEIRA, E. S. Parâmetros para avaliar a produção literária em História e Filosofia da Ciência voltada para o ensino e divulgação das ideias da Física. Caderno Brasileiro de Ensino de Física, Florianópolis, v. 30, n. 3, p. 471-491, 2013. Disponível em: $<$ https://periodicos.ufsc.br/index.php/fisica/article/view/2175-7941.2013v30n3p471>. Acesso em: 26 mar. 2016.

PORTELA, S. I. C. O uso de casos históricos no Ensino de Física: Um exemplo em torno da temática do horror da natureza ao vácuo. 2006. Dissertação (Mestrado) - UnB. Disponível em: $<$ http://bdtd.bce.unb.br/tedesimplificado/tde_busca/arquivo.php?codArquivo=1502>. Acesso em: 10 mai. 2015.

QUINTAL, J. R.; GUERRA, A. A história da ciência no processo de ensino e aprendizagem. A Física na escola, São Paulo, n. 10, p. 21-25, 2009. Disponível em: <http://www.sbfisica.org.br/fne/Vol10/Num1/a04.pdf>. Acesso em: 25 mar. 2016. 
REKOVVSKY, L. Textos de Apoio ao Professor de Física, Porto Alegre, IF - UFRGS, v. 23, n. 5, p. 1-60, 2012. Disponível em:

<http://www.if.ufrgs.br/public/tapf/v23_n5_rekovvsky.pdf>. Acesso em: 25 mar. 2016.

SALTIEL, E.; VIENNOT, L. Qué aprendemos de las semejanzas entre las ideas historicas y el razonamiento espontáneo de los estudiantes? Enseñanza de las Ciencias, v. 3, n. 1, p. 137144, 1985. Disponível em: <http://www.raco.cat/index.php/Ensenanza/article/view/51883>. Acesso em: 4 mai. 2015.

SASSERON, L. H.; BRICCIA, V., CARVALHO, A. M. P. Aspectos da natureza das Ciências em sala de aula: exemplos do uso de textos científicos em prol do processo de Alfabetização Científica dos estudantes. In: SILVA, C. C.; PRESTES, M. E. B. (Org.) Aprendendo ciência e sobre sua natureza: abordagens históricas e filosóficas. São Carlos: Tipographia, 2013. p. 265-276.

SILVA, A. P. B.; GUERRA, A. História da Ciência e Ensino: Fontes Primárias e propostas para sala de aula. São Paulo: Editora Livraria da Física, 2015.

SILVEIRA, F. L. A Filosofia da Ciência e o Ensino de Ciências. Em Aberto, Brasília, v. 11, n. 55, p. 36-41, jul./set. 1992.

SOLAZ-PORTOLÈS, J. J.; MORENO-CABO, M. El espacio vacío y sus implicaciones en la historia de la ciencia. Caderno Brasileiro de Ensino de Física, Florianópolis, v. 14, n. 2, p. 194-208, ago. 1997. Disponível em: <https://periodicos.ufsc.br/index.php/fisica/article/viewFile/7033/6509>. Acesso em: 7 mai. 2015.

SOLAZ-PORTOLÈS, J. J. Concepciones de los estudiantes e Historia de la ciencia: el caso del concepto de vacío. [S. 1.: s. n.], 2008. Disponível em: <www.eumed.net/libros/2008c/451/>. Acesso em 7: mai. 2015.

TEIXEIRA, E. S.; GRECA, I. M.; FREIRE JR, O. Uma revisão sistemática das pesquisas publicadas no Brasil sobre o uso didático de história e filosofia da ciência no ensino de física. In: PEDUZZI, L. O. Q.; MARTINS, A. F. P., FERREIRA, J. M. H. (Org.). Temas de história e filosofia da ciência no ensino. Natal: EDUFRN, 2012. Cap. 1, p. 9-40

VIDEIRA, A. A. P. Historiografia e história da ciência. Escritos (Fundação Casa de Rui Barbosa), Rio de Janeiro, v. 1, p. 111-158, 2007. Disponível em: <http://www.casaruibarbosa.gov.br/escritos/numero01/FCRB_Escritos_1_6_Antonio_Augusto_Passos_Videira.pdf>. Acesso em: 10 mai. 2015.

VILLATORRE, A. M.; HILGA, I.; TYCHANOWICZ, S. D. Didática e avaliação em física. Curitiba: Editora Ibpex, 2008. 
VITAL, A.; GUERRA, A. A natureza da ciência no ensino de física: estratégias didáticas elaboradas por professores egressos do mestrado profissional. Caderno Brasileiro de Ensino de Física, Florianópolis, v. 31, n. 2, p. 225-257, ago. 2014. Disponível em: <https://periodicos.ufsc.br/index.php/fisica/article/viewFile/21757941.2014v31n2p225/27317>. Acesso em: 3 jul. 2015.

XAVIER, E. S. O uso de fontes históricas como ferramentas na produção do conhecimento histórico: a canção como mediador. Antíteses, Londrina, v. 3, n. 6, p. 1097-1112, 2010. Disponível em: <http://www.uel.br/revistas/uel/index.php/antiteses/article/view/5062>. Acesso em: 17 mai. 2015. 


\section{Apêndice 1}

\section{(1) UMO VOCÊE EXPLICA...}

A maioria de nós já tomou algum líquido, como suco, refrigerante ou água, utilizando um canudo de plástico. Você já parou para pensar...

POR QUE O LÍQUIDO SOBE ATRAVÉS DO CANUDO?

Rotineiramente, no verão, o consumo de água nas ruas aumenta. Podemos comprar uma garrafinha de água e tomá-la com o auxílio de um canudinho. Você já parou para refletir...

SE O CANUDO ESTIVER FURADO,

VAI OCORRER A SUBIDA DO LÍQUIDO?

\section{Aciência éuma}

tentativa de

explicar fenômenos

naturaís! 


\section{Desde a antiguidade, fenômenos naturais já despertavam o}

interesse dos pesquisadores. Vejamos alguns exemplos...

"Se retíramos o ar do sifão através da extremidade externa, a agua ira imediatamente seguír por causa da impossibilidade de um vácuo contínuo no sifão[...]"

Heron de Alexandria, Séc. 1 d. c.

"Considero que a natureza tem horror ao vazío. Quando colocamos a extremidade de um canudo na boca e mergulhamos a outra extremidade no vinho... sugamos o ar do canudo, atrai-se o vinho para cima, embora ele seja pesado. Isso ocorre porque é necessário que algum corpo sempre venha logo depois do ar que é sugado para cima, para evitar a formaçäo de um vácuo [...]."

Jean Buridan, séc. XIV.

Que fenômeno Buridan estava tentando explicar?

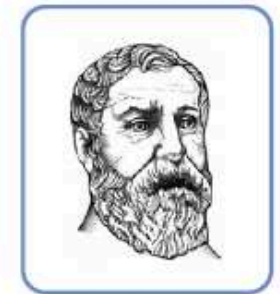

Figura 1: Heron de Alexandria

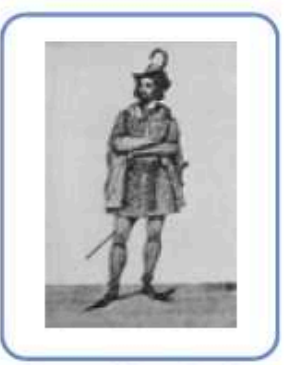

Figura 2: Jean Buridan

No momento 1, quando tentamos explicar esse fenômeno, pensamos em algo fora do canudo? E, Buridan, como ele pensou?

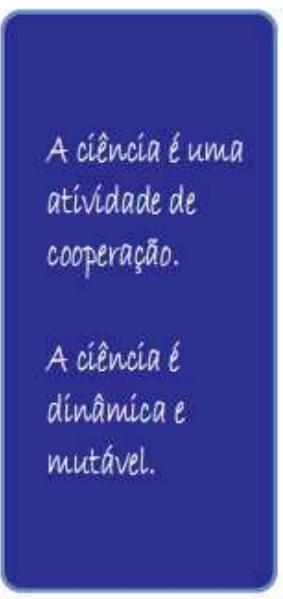




\section{(2) O AR TEM PESO?}

Desde a antiguidade, pesquisadores se preocuparam com essa questão. Por volta do século XVII, a ideia de que o ar tinha peso e exercia pressão era cada vez mais aceita. Esse novo pressuposto teórico podia levar a uma reinterpretação de fenômenos antes atribuídos ao horror ao vazio. A subida do líquido pelo canudinho era um exemplo.

[...] $o$ ar é pesado [...I a evidência disso é que uma bexiga cheía pesa mais do que quando vazia.

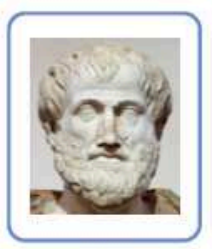

Figura 3: Aristóteles

Aristb́teles, sec. IV a, c.

A conclusão de Aristóteles não foi bem aceita na época. Três séculos depois, o pensador grego Simplício afirmou que havia repetido o experimento de Aristóteles sem sucesso. Segundo Simplício, Aristóteles teria se equivocado: ao soprar a bexiga teria inserido umidade em seu interior, causando a diferença do peso.

"O ar é pesado [... el ele nos pressiona de todos os lados de um modo uniforme". "As coisas se precipitam para um espaço vazio com grande força, por causa da imensa altura do ar acima"

Isaac Beeckman, Séc. XVI.

o que Beeckman quis dizer quando afirmon que "o ar nos pressiona de todos os lados"? Podemos sentir esse efeito? Será que ele discordaría de Euridan sobre o problema do canudinho?

Figura 4: Isaac Beeckman 


\section{(3) Oue encontramos no livro didático?}

PRESSÃO ATMOSFÉRICA

Em um recipiente usado em experiências de laboratório, ou mesmo dentro de uma ampla sala, o peso do ar tem pouca influência na pressão por ele exercida. [...] se dividirmos o peso do ar de uma sala $(768 \mathrm{~N})$ pela área do piso $\left(24 \mathrm{~m}^{2}\right)$, teremos uma pressão de apenas $32 \mathrm{~Pa}$. Esse valor é insignificante quando comparado aos $10^{5} \mathrm{~Pa}$ da

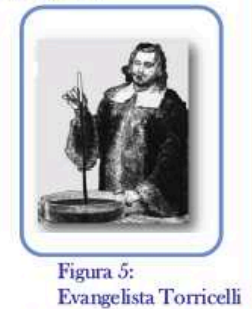
atmosfera terrestre. Por outro lado, a atmosfera terrestre é um "recipiente" tão alto (cerca de $500 \mathrm{~km}$ de altura) que a contribuição gravitacional à pressão torna-se extremamente importante. Se desenharmos no chão, no nível do mar, um quadrado de $10 \mathrm{~cm}$ de lado, a "coluna de ar" acima dele terá massa de $100 \mathrm{~kg}$. A massa total da atmosfera terrestre é aproximadamente 5.300 trilhões de toneladas, ou seja, não é nada desprezível. Devido à distribuição não uniforme do ar atmosférico, a pressão atmosférica diminui à medida que nos afastamos da superfície da terra, conforme representado na figura abaixo que representa a variação da pressão atmosférica com a altitude.

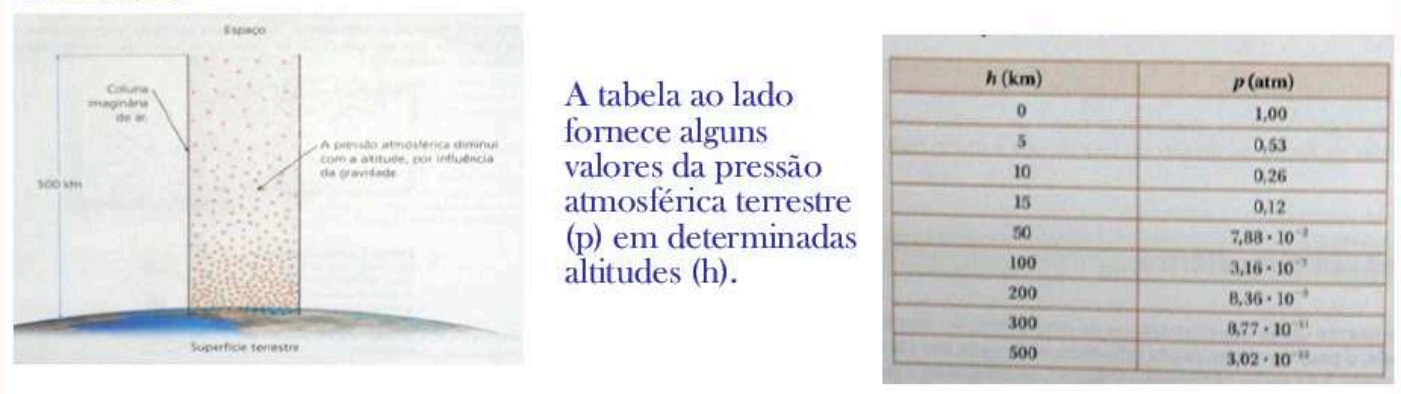

\section{EXPERIÊNCIA DE TORRICELLI}

O barômetro, utilizado para medir a pressão atmosférica, é um dos instrumentos básicos na Meteorologia. A figura ao lado mostra o arranjo experimental necessário para a realização da experiência de Torricelli. Nesse arranjo, o tubo de vidro é totalmente preenchido com mercúrio $(\mathrm{Hg})$ e emborcado em um recipiente contendo também mercúrio. Na parte superior do tubo, fica uma região denominada "vácuo torricelliano", que, na verdade, encerra um pouco do vapor do líquido. Porém a pressão exercida por esse vapor é desprezível quando comparada com a pressão atmosférica. No nível do mar, observa-se que a coluna de mercúrio dentro do tubo eleva-se a aproximadamente $76 \mathrm{~cm}$ acima do nível de mercúrio do recipiente. Assim, podemos medir a pressão em "altura" de coluna de líquido.

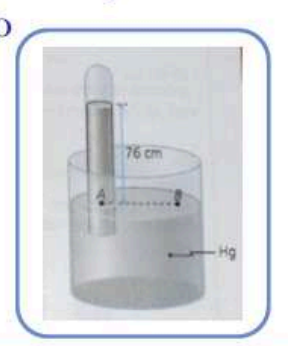


O livro didático apresenta o conceito de pressão atmosférica de forma simples e direta, mas será que esse conceito foi utilizado e aceito tão facilmente? Vamos pensar...

Por meío do experimento de Torricelli era mesmo possivel concluir que a sustentação do mercúrio se devía a algo externo (pressão)? Explique.

De acordo com a ideía de pressão atmosférica, o fenômeno do canudinho podería ser interpretado de outra maneira, diferente da sugerida por Buridan? o que será que as pessoas pensavam sobre isso na época de Torricellí? Explique. 


\section{(4) A ENTREVista COM TORRICELli}

Neste momento, vamos ver uma entrevista fictícia com o pesquisador Evangelista Torricelli. A entrevista não é real, representa o que ele gostaria de dizer, as intencionalidades desse personagem. Os trechos sublinhados são autênticos. São mesmo as palavras de Torricelli que foram resgatadas de documentos escritos por ele.

Vamos refletir um pouco...

\section{Será que Torricelli teve alguma dificuldade? Ele chegou mesmo a uma conclusão final?}

Tomando como base a consideração de que o ar tem peso e exerce pressão, como podería ser explicada a subida do líquído através do canudo quando tomamos suco/refrigerante? 
Lista de Figuras:

Figura 1: https://pt.wikipedia.org/wiki/Heron_de_Alexandria

Figura 2: https://nambiquarablog.wordpress.com/2012/11/19/filosofosmedievais-iv/

Figura 3: https://pt.wikipedia.org/wiki/Arist\%C3\%B3teles

Figura 4: http://www.classtools.net/FB/1305-FBiGXb

Figura 5: https://sites.google.com/site/kurtzeppetello/featured-scientist

Para aprofundamento:

MARTINS, R. A. O vácuo e a pressão atmosférica, da antiguidade a Pascal. Cadernos de História e Filosofia da Ciência [série 2] 1(3): 9-48, 1989.

Disponível em: http://www.ghtc.usp.br/ram-r33.htm 
Apêndice 2

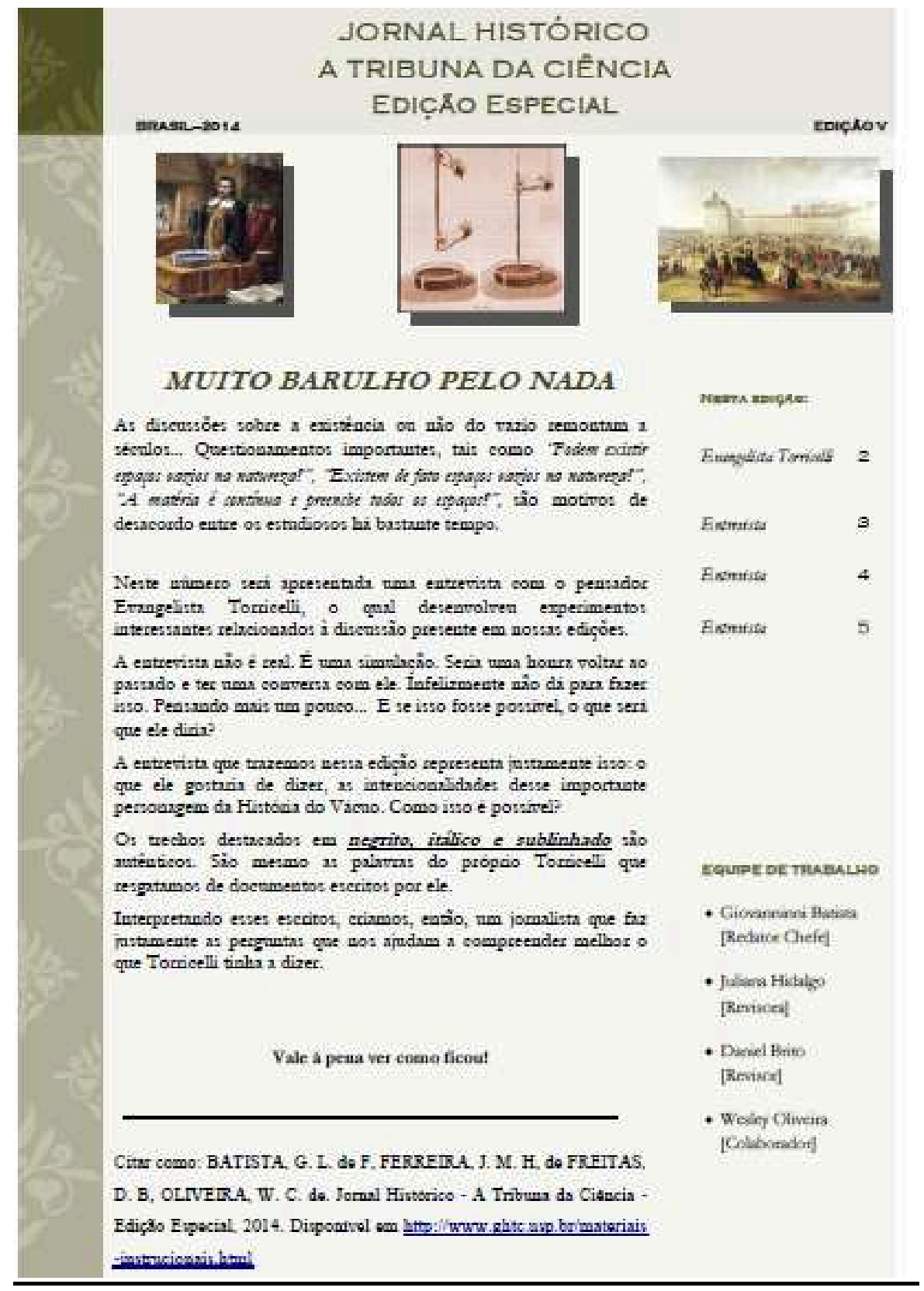


Jornalista: Então... Existe ○ vazio ou naีo?

Torricelli: Fizemos muitos recipientes de vidro como aqueles mostrados em $\mathrm{A}$ e B (fig. X) com tubos de dois cúbitos de comprimento. Estes foram preenchidos com mercúrio, suas extremidades fechadas com o dedo, e foram, então, invertidos em um recipiente $C$ onde havia mercúrio; vimos que um espaço vazio foi formado e que nada aconteceu no tubo onde esse espaço foi formado; o tubo entre $A \& D$ permaneceu sempre cheio até a altura de um cúbito $e$ um quarto $e$ uma polegada. Para mostrar que o tubo estava completamente vazio, enchemos a bacia com água pura até $\mathrm{D}$ e então, erguendo o tubo pouco a pouco, vimos que, quando a abertura do tubo alcançou $a$ água, o mercúrio caiu do tubo e a água subiu com grande violência até

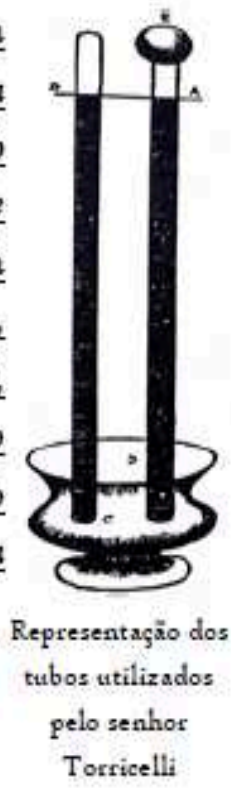

Jornalista: Então o senhor está aceitando que o vácuo existe?

Torricelli: Muitos disseram que o vácuo não existe, outros que de fato existe apesar da repugnância da natureza e com dificuldade; eu não conheço alguém que tenha dito que exista sem dificuldade e sem uma resistência da natureza. Aceito a existência do vácuo, mas ele ocorre com alguma resistência na natureza.
Jornalista: Mas se o vácuo existe, ele não seria a causa da sustentação da coluna de mercúrio? Ele não daria um puxão, como dizem? Para o senhor, então, o que sustenta a coluna de mercúrio?

Torricelli: Costuma ser dito como explicação para of ato de que o tubo $A E$ permanece vazio e - mercúrio, embora pesado, seja sustentado no tubo AC, que, como se acredita até agora, a força que impede que o mercúrio caia, como naturalmente of faria, é interna ao tubo $\mathrm{AE}, e$ provém do vácuo ou de alguma substância extremamente rarefeita; mas afirmo que é externa, e que essa força vem de fora. 
Jornalista: Como assim? Que força seria essa?

Torricelli: Vivemos imersos no fundo de um oceano de ar elementar, o qual, por experimento, sem dúvida tem peso, $\varepsilon$ tanto peso que o ar mais denso na vizinhança da superfície da terra pesa cerca de uma quatro-centésima parte do peso da água. Esse peso, determinado por Galileu, podemos considerar que se aplique à atmosfera mais baixa, onde os homens $e$ os animais vivem, enquanto que nos picos das altas montanhas o ar começa a se tornar mais puro e a pesar muito menos do que a quatro-centésima parte do peso da água. No nosso caso, estamos realizando o experimento na superfície da terra.. Sobre a superfície do líquido que está na bacia repousa o peso de uma [coluna de] altura de cinquenta milhas de ar; então, e se no tubo $C E$, no qual o mercúrio não sofre tendência ou repugnância alguma, nem mesmo mínimas, a estar lá, devesse entrar e subir uma coluna alta o suficiente para entrar em equilibrio com o peso do ar exterior que of força a subir?

Jornalista: Mas mesmo considerando que $O$ ar tem peso $e$ atua sobre o mercúrio, ainda assim poderíamos considerar que aquele espaço vazio ou com alguma substância bem rarefeita tem alguma influência na altura da coluna de mercúrio?

Torricelli: A água em um tubo similar, embora mais longo, subirá até cerca de 18 cúbitos, isto $\dot{e}_{2}$ [sobe] tanto mais do que aquilo que o mercúrio sobe, o quanto ele é mais pesado do que a água; de forma a haver um equilibrio com a mesma causa que atua sobre um e sobre o outro. Este argumento $\dot{e}$ reforçado por um experimento feito simultaneamente com o tubo $A$ e com o tubo $B$, no qual o mercúrio sempre permanece na mesma linha horizontal $A B$. Isso deixa quase que certo que a ação não se origina de dentro; por que o vaso $A E$, onde haveria mais substância rarefeita, deveria ter exercido uma força maior, atraindo muito mais ativamente, por causa da maior rarefação, do que se observa no espaço menor $B$. Tenho me empenhado em explicar por esse princípio todos os tipos de repugnâncias que são sentidas em vários efeitos atribuídos ao vácuo, $e$ ainda não encontrei

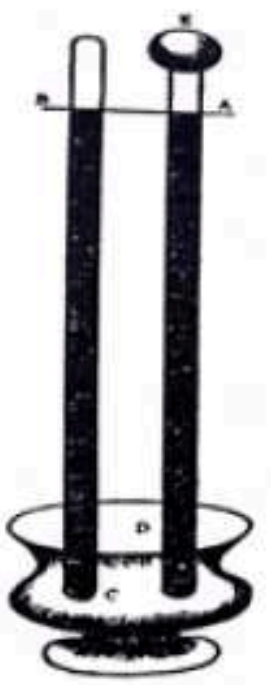

Representação dos tubos utilizados pelo senhor Torricelli alguma com a qual não consiga lidar com sucesso. [...] parece-me tolice tentar atribuir ao vácuo aquelas operaçöes que se seguem evidentemente de alguma outra causa. 
Jornalista: Parece que o senhor realmente está interessado nesse assunto. Por quê?

Torricelli: Eu e vários senhores com os quais tenho me correspondido como os senhores Michelangelo Ricci, Antonio Nardi e Magiotti. Escrevi ao senhor Ricci relatando os resultados que agora the apresentei. Disse a ele: "irá perceber muitas objeções, mas espero que se o senhor pensar sobre elas, as mesmas sejam resolvidas". Eu já havia chamado a atenção para o fato de que estão sendo realizados certos experimentos filosóficos, não sei exatamente o que, relacionados ao vácuo, elaborados não simplesmente para produzir vácuo, mas para chegar a um instrumento que nos mostrará as mudanças na atmosfera, se está agora mais pesada e densa e depois mais leve $e$ sutil.

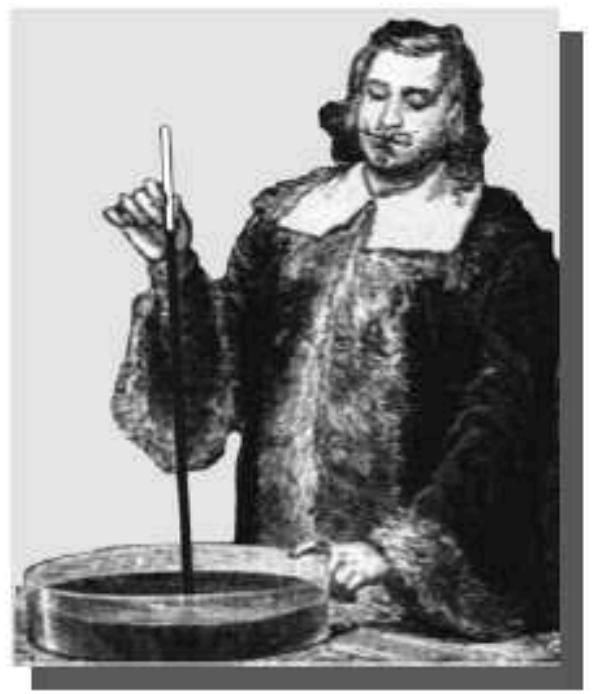

Jornalista: Estudar as mudanças na atmosfera... mas, isso seria ótimo! O senhor está encontrando alguma dificuldade na realização desse trabalho? Já tem resultados convincentes?

Torricelli: Exatamente. Minha intenção principal é reconhecer quando a atmosfera é mais densa e mais pesada e quando é mais sutil e mais leve. Mas ainda não fui capaz de concretizá-la porque o nível $A B$ no instrumento $E C$ varia por alguma outra razão, o que eu não teria acreditado, especialmente como se fosse sensível ao frio ou ao calor, exatamente como se o tubo AE estivesse cheio de ar.

Jornalista: Isso é estranho... O senhor não disse que o tubo estava vazio? Bem, não quero aborrecê-lo. Sabemos que essa é uma pergunta muito complicada. E que, por outro lado, é justamente a dúvida e não a certeza que estimula o pesquisador. Nossos leitores agradecem ao ilustre pesquisador e vamos continuar acompanhando de perto suas pesquisas! 